\title{
Grassland vegetation of Hodrušská hornatina highland in Central Slovakia
}

\section{Alexandra Klimantová ${ }^{1}$}

Key words: grasslands, ordination, Slovakia, species richness, syntaxonomy, Štiavnické vrchy Mts., threatened species.

Ključne besede: travišča, ordinacija, Slovaška, vrstna pestrost, sintaksonomija, gorovje Štiavnické vrchy, ogrožene vrste.
Received: 31. 3. 2016

Revision received: 13. 2. 2017

Accepted: 22. 2. 2017

\begin{abstract}
This paper is focused on the grassland communities in Hodrušská hornatina highland, Central Slovakia. We studied grasslands at 153 sites during the vegetation periods of 2013-2015 and recorded 303 species of vascular plants in the studied localities. The species richness ranged from 16 to 66 taxa per relevé. Data analysis (TWINSPAN, DCA) grouped the relevés into eight clusters. These clusters include five associations from three alliances: Holcetum lanati (Deschampsion cespitosae), Pastinaco sativae-Arrhenatherum elatioris, AlchemilloArrhenatheretum elatioris, Anthoxantho odorati-Agrostietum tenuis (all from Arrhenatherion elatioris) and Onobrychido viciifoliae-Brometum erecti (Bromion erecti). The other three clusters represent the transitional and successional stages of the communities listed above. A brief description of syntaxa is given. At some sites, the threatened, rare or protected taxa of Slovakia occurred as well, one from each of the categories of Critically Endangered and Vulnerable, nine species of the Nearly Threatened and six species from the category of Least Concerned.
\end{abstract}
Izvleček
V članku obravnavamo travniške združbe na hribovju Hodrušská hornatina na osrednjem Slovaškem. V obdobju 2013-2015 smo preučili travišča na 153 lokacijah in zabležili 303 vrste rastlin. Vrstna pestrost je bila med 16 in 66 taksonov na vegetacijski popis. Analiza podatkov (TWINSPAN, DCA) je pokazala združevanje popisov v osem klastrov. Ti šopi vključujejo pet asociacij iz treh zvez: Holcetum lanati (Deschampsion cespitosae), Pastinaco sativae- Arrhenatherum elatioris, Alchemillo-Arrhenatheretum elatioris, Anthoxantho odorati- Agrostietum tenuis (vsi iz zveze Arrhenatherion elatioris) in Onobrychido viciifoliae- Brometum erecti (Bromion erecti). Ostali trije klastri predstavljajo prehodne in sukcesijske stadije zgoraj omenjenih združb. Predstavili smo kratek opis združb. Na določenih lokacijah uspevajo tudi ogrožene, redke ali zaščitene rastlinske vrste. Ena spada v kategorijo skrajno ogrožene in ranljive vrste, devet med potencialno ogrožene vrste in šest med najmanj ogrožene vrste. 


\section{Introduction}

Since the beginning of the $20^{\text {th }}$ century, when the research on European meadows started (e.g. Braun-Blanquet 1930), a large number of surveys on grasslands across Europe have been carried out. Species-rich grassland communities were described, for example, in the north of Scandinavia (Dierssen 1996), and Estonia (Kull \& Zobel 1991, Kukk \& Kull 1997, Sammul et al. 2003), in Central Europe in the Alps (Mucina et al. 1993, Tasse \& Tappeiner 2002), in the Czech Republic and Slovakia (Chytrý et al. 2007, Janišova et al. 2007), in Hungary (Borhidi \& Sánta 1999, Botta-Dukát et al. 2005, Borhidi et al. 2012), and in the south of the Balkans (Aćić et al. 2015), in Bulgaria (Velev \& Vassilev 2014) or Croatia (Stančić 2008).

Slovakia is a small country in Central Europe with rather diverse relief, climate and geology. Its geographic position determines a rich flora. The majority of the country falls into the Western Carpathian region, but the Eastern Carpathian and Pannonian regions are also present. Following the phytogeographic division suggested by Futák (1966), the bordering of the two regions (Carpathian and Pannonian) allows the intersection of the Pannonian and Carpathian vegetation components. Natural grasslands have developed here only in the ecologically extreme habitats (Hájková et al. 2001), and local grasslands are closely connected with human activities. Several hundred years of human agricultural activities resulted in the rise of very valuable habitats with secondary plant communities (Novák 2008). In comparison with other communities, the grasslands of the European temperate zone are noted for their rich flora and high diversity (Pärtel et al. 1996, Šeffer et al. 2002). Many of them are also listed as the habitats of European importance, in Annex I, of the Habitats Directive (Council Directive 92/43/EEC on the conservation of natural habitats and wild fauna and flora). In Slovakia, the grassland area significantly expanded during the $18^{\text {th }}$ and $19^{\text {th }}$ centuries alongside the expansion of agriculture (Ružičková \& Kalivoda 2007). In 1920, more than one million hectares of grassland was registered in Slovakia. However, due the changing political situation, their area has been consistently declining in the last decades (Galvánek \& Viestová 2006, Ružičkové \& Kalivoda 2007, Novák 2009, Ružičková et al. 2011). Unmanaged areas usually successionally change towards scrub and forest vegetation (Moog et al. 2002). A large number of publications have focused on grassland research in Slovakia. Among the first were the studies by Futák (1943, 1947), Jurko (1951) and Májovský (1953). Many studies focused on classification and syntaxonomy of grasslands (Jurko 1974, Michálková, Janišová et al. 2008, Janišová et al. 2010a, b, Hegedüšová et al. 2011).
The synthesis of phytosociological data from Slovakia was completed in the fifth volume of the Vegetation of Slovakia (Hegedüšová Vantarová \& Škodová 2014), devoted to grassland vegetation.

Slovak grasslands are generally quite well-known, and some case studies were published also from Central Slovakia, including the Štiavnické vrchy mountains (Ružičková 1986, Ružičková \& Halada 2005, Banásová et al. 2006, Hegedüšová \& Ružičková 2007). In spite of this knowledge, there is no comprehensive study from the area of Hodrušská hornatina highland (western part of Štiavnické vrchy mountains in Central Slovakia).

The aim of this study is ( $i$ ) to complete the information on the syntaxa of grassland vegetation in Hodrušská hornatina highland, (ii) assess the variability of plant communities and (iii) highlight the presence of threatened species.

\section{Study Area}

The study area is situated in the western part of the Štiavnické vrchy mountains in Central Slovakia (Figure 1). The area of Hodrušská hornatina highland is more than 35,136 ha. The study area is part of the largest volcanic mountain range of the Western Carpathians (Miklós \& Izakovičová 2006). The lowest point of the area is $232 \mathrm{~m}$ a.s.l. and the highest is $939 \mathrm{~m}$ a.s.l., so the vertical dissection is $707 \mathrm{~m}$. The bedrock of the area is mainly formed by andesite, granite, and limestone in some parts. The prevailing soil type in the territory of Hodrušská hornatina highland is cambisol. The rendzinas are mostly associated with the limestone bedrock (Miklós \& Hrnčiarová (eds.) 2002). Fluvisols are the dominant soil type along rivers and springs (Kunca et al. 2005). The studied area belongs to the moderately warm climate region with average temperatures from $6{ }^{\circ} \mathrm{C}$ to $10{ }^{\circ} \mathrm{C}$. Summers are relatively short and dry, with average temperatures of the hottest month between $15^{\circ} \mathrm{C}$ and $19^{\circ} \mathrm{C}$. On the other side, average temperatures of the coldest month are between $-1{ }^{\circ} \mathrm{C}$ and $-5^{\circ} \mathrm{C}$. The annual precipitation is 700 $900 \mathrm{~mm}$ (SHMÚ 2015). The majority of the territory is covered in forests; mixed oak-hornbeam forests (Carpinion betuli) and beech forests (Fagion sylvaticae) dominate.

\section{Methods}

In our research we focused on semi-natural grasslands developed and maintained by human activity. We set the sample plots to cover most of the grasslands in the study area. They included meadows with intensive and extensive management, pastures, orchards, and even 
abandoned grasslands. A total of 153 phytosociological relevés were made across the study area. The survey was carried out within three vegetation periods (2013-2015), according to the Zürich-Montpellier methodological approach (Braun-Blanquet 1964). The sample plots were squares, with the area of $25 \mathrm{~m}^{2}$ each, which is recommended for grasslands (Chytrý \& Otýpková 2003). The nine-element ordination scale (van der Maarel 1979) was used for the estimation of species abundance. The relevés were entered into the Turboveg database management program (Hennekens \& Schaminée 2001). The numerical classification was performed by TWINSPAN classification (Hill 1979), carried out using the software JUICE (Tichý 2002). We have used the crispness of classification to determine the optimal number of clusters (Botta-Dukát et al. 2005). Based on the highest Actual Average Crispness Value, the data were divided into eight groups. Diagnostic species for the clusters in the data set were determined by calculation of species fidelity to each cluster, using the phi coefficient in JUICE (Chytrý et al. 2002). The threshold fidelity value for diagnostic species was set to phi $=0.20$. Non-significant fidelity values were excluded using Fisher's exact test $(\mathrm{P}<0.001)$. For the interpretation of position and relations between the communities, a Detrended Correspondence Analysis (DCA) was carried out in CANOCO 4.5 for Windows package (ter Braak \& Šmilauer 2002). For environmental characterization of vegetation groups, the Ellenberg indicator values for soil reaction, moisture, nutrient content, temperature, and continentality, were used (Ellenberg et al. 1992). Some environmental data (altitude, slope, aspect and applied management) were also collected in the field. The heat index was calculated according to the formula: heat index $=\cos \left(\right.$ aspect $\left.-225^{\circ}\right) \times \operatorname{tg}$ (slope) (Parker 1988). The management was encoded as intensively managed, extensively managed, and abandoned. These data were plotted onto the DCA ordination diagram as supplementary environmental variables. For the nomenclature of vascular plants, the list of Marhold \& Hindák (1998) was used. A list of vegetation units of Slovakia (Hegedüšová Vantarová \& Škodová 2014) was used for the nomenclature of grassland communities. The threatened species were assessed according to the recent Red list of ferns and flowering plants of Slovakia (Eliáš et al. 2015).

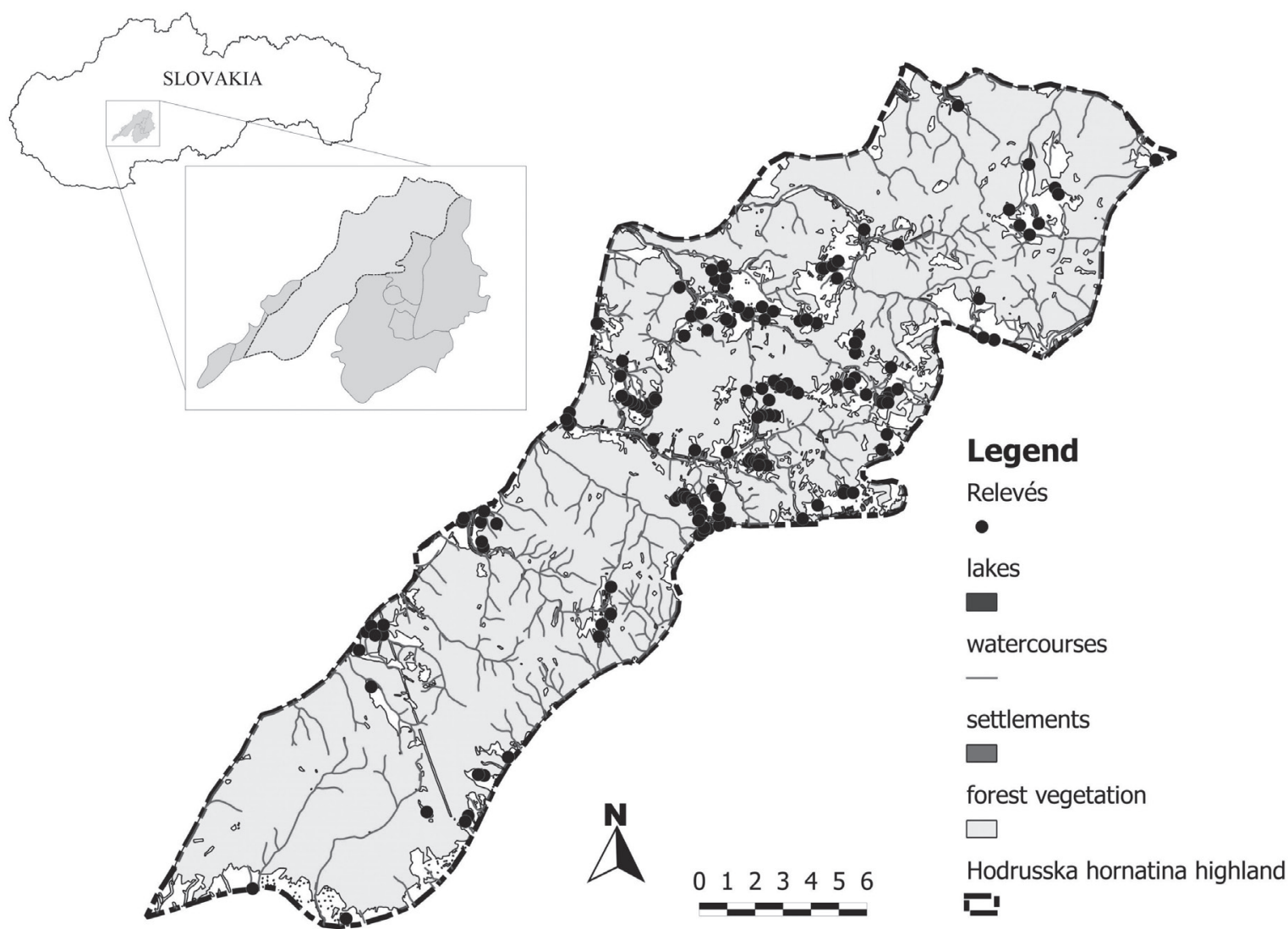

Figure 1: Location of the study area in the Slovak Republic. Black points show the location of relevé plots. Slika 1: Lokacija preučevanega območja na Slovaškem. Črne točke predstavljajo lokacije popisnih ploskev. 


\section{Results}

In total, we sampled 153 phytosociological relevés in Hodrušská hornatina highland and recorded 303 species of vascular plants. The species richness ranged from 16 to 66 taxa per relevé (on average 41.8 species). Using TWINSPAN, we classified the relevés into eight clusters. We were able to distinguish two classes MolinioArrhenatheretea R. Tx. 1937 and Festuco-Brometea Br.-Bl. et R. Tx. ex Soó 1947. Nine relevés were assigned to the association Holcetum lanati Issler 1936, 37 relevés were classified as Pastinaco sativae-Arrhenatheretum elatioris Passarge 1964, 33 relevés as Alchemillo-Arrhenatheretum elatioris Sougnez et Limbourg 1963, 30 relevés as Anthoxantho odorati-Agrostietum tenuis Sillinger 1933 and five relevés as Onobrychido viciifoliae-Brometum erecti T.Müller 1966. The relevés that could not be assigned to associations due their transitional character were classified to the alliance level (Arrhenatherion elatioris Luquet 1926 and Bromion erecti Koch 1926). A subsequent Detrended Correspondence Analysis (DCA) has confirmed this classification (Figure 2). The total inertia in the DCA was 5.71; eigenvalues were 0.249 (axis 1) and 0.167 (axis 2). The first axis explained $4.4 \%$ of the variance of species data, the second axis $2.9 \%$. The first axis was positively correlated with light (correlation coefficient 0.4200 ) and negatively correlated with nutrient content and moisture (correlation coefficient -0.8980 and -0.8134 ). This fact suggests that the main gradient in our dataset is related to light, nutrient content and moisture. The kind of applied management proved to be rather important. The abandonment was positively correlated with the first axis (0.3427), intensive type of management (-0.4392) and mown grasslands $(-0.2024)$ were negatively correlated with it. Most of the relevés were concentrated in the central part of the DCA diagram. This fact is explained by the small differences in species composition between mesophilic associations within the alliance Arrhenatherion elatioris (Anthoxantho odorati-Agrostietum tenuis, Alchemillo-Arrhenatheretum elatioris, Pastinaco sativae-Arrhenatheretum elatioris) and all their transitional and successional phases. Relevés from intensified meadows of the association Pastinaco sativaeArrhenatheretum elatioris were clearly separated in the left part of the graph, following the nutrient content gradient. Wetter association Holcetum lanati were also situated more in the left part of the graph. Relevés of dry grasslands from the alliance Bromion erecti were, on the other side, in the right part. The second axis was positively correlated with soil reaction (0.6529), temperature (0.4780) and continentality $(0.3967)$. Some outliers might be caused by differences in species composition due to management type, succession changes, or changes in water regime at the site. Our syntaxonomical scheme follows the concept for grassland vegetation in Slovakia (Hegedüšová Vantarová \& Škodová 2014).

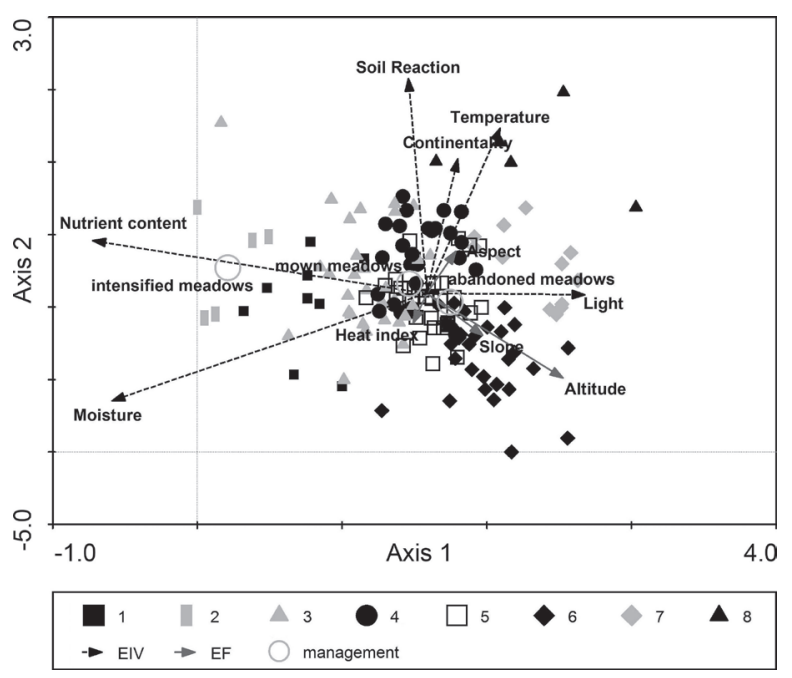

Figure 2: Detrended Correspondence analysis (DCA) ordination diagram of phytosociological relevés based on average Ellenberg indicator values and environmental factors. Syntaxa are marked as follows: 1 Holcetum lanati, 2 Pastinaco sativae-Arrhenatheretum elatioris - intensive meadows, 3 Pastinaco sativae-Arrhenatheretum elatioris, 4 Alchemillo-Arrhenatheretum elatioris, 5 Arrhenatherion elatioris, 6 Anthoxantho odorati-Agrostietum tenuis, 7 Brometalia erecti, 8 Onobrychido viciifoliae-Brometum erecti.

Slika 2: Ordinacijski diagram korespondenčne analize z odstranjenim trendom (DCA) fitocenoloških popisov in povprečnih Ellenbergovih indikatorskih vrednosti in okoljskih dejavnikov. Sintaksoni so označeni kot: 1 Holcetum lanati, 2 Pastinaco sativae-Arrhenatheretum elatioris - intensive meadows, 3 Pastinaco sativae-Arrhenatheretum elatioris, 4 Alchemillo-Arrhenatheretum elatioris, 5 Arrhenatherion elatioris, 6 Anthoxantho odorati-Agrostietum tenuis, 7 Brometalia erecti, 8 Onobrychido viciifoliae-Brometum erecti.

The hierarchical system of syntaxa

Molinio-Arrhenatheretea R. Tx. 1937

Molinion caeruleae Koch 1926

Deschampsion cespitosae Horvatić 1930

Holcetum lanati Issler 1936

Arrhenatheretalia R. Tx. 1931

Arrhenatherion elatioris Luquet 1926

Pastinaco sativae-Arrhenatheretum elatioris Passarge 1964

Alchemillo-Arrhenatheretum elatioris Sougnez et Limbourg 1963

Anthoxantho odorati-Agrostietum tenuis Sillinger 1933

Festuco-Brometea Br.-Bl. et R. Tx. ex Soó 1947

Brometalia erecti $\mathrm{Br}$.-Bl. 1936

Bromion erecti Koch 1926

Onobrychido viciifoliae-Brometum erecti $\mathrm{T}$. Müller 1966 
The association Holcetum lanati included plant communities dominated by grass species Poa pratensis, Alopecurus pratensis, Festuca pratensis and Holcus lanatus. The total coverage of the herb layer mostly reached $100 \%$. The association was recorded at altitudes between 238 and $387 \mathrm{~m}$ a.s.l. The average number of species per relevé was 35. The spring aspect was formed of herbs Cardamine pratensis, and the early summer aspect of Ranunculus acris and Lychnis flos-cuculi. Lysimachia nummularia and Plantago lanceolata formed the undergrowth. The gradient of moisture is correlated with relevés of this association. This vegetation mostly occurs on river alluviums. Higher water supply in spring and desiccation during summer is typical for this community. Transition towards the mesophilous alliance of Arrhenatherion elatioris was common during spring periods with water absence. Species as Campanula patula, Crepis biennis, Equisetum arvense, Leontodon hispidus, Leucanthemum vulgare, Pastinaca sativa and Veronica chamaedrys were of higher constancy in these relevés.

The second and third group represent the association of Pastinaco sativae-Arrhenatheretum elatioris. The gradient of soil nutrient content and moisture are correlated with the association, especially the second group associated with high values. Species-poor meadows of the second group were intensively managed. In consequence of the high nutrition content, coming from fertilization, high grasses such as Arrhenatherum elatius, Dactylis glomerata, Festuca pratensis and Poa pratensis predominated. The number of species fluctuated from 26 to 37 species, 32 on average. Knautia arvensis and Crepis biennis were the species with higher constancy. The undergrowth was mainly composed of shade-tolerant species Achillea millefolium, Trifolium pratense, Trifolium repens and the species of Taraxacum sect. Ruderalia. Some ruderal species occurred as well (Cirsium arvense, Potentilla reptans). The grasslands of the third group had higher species richness, on average 39 species per relevé. Some of them were orchards, meadows, and extensively used or abandoned meadows. Within the third group, we distinguished two variants of the above mentioned association - one variant with Geranium pratense and one, more frequent variant, with Anthriscus sylvestris. The first variant was characterised by species such as Centaurea elatior, Crepis biennis, Filipendula vulgaris, Geranium pratense, Taraxacum sect. Ruderalia, Trifolium repens, and Trisetum flavescens. It occupied sites in cold hollows, on river banks, and on deep soils with higher nutrient and water content. On the other hand the second variant was connected with warmer, occasionally ploughed sites. The constant species were Anthriscus sylvestris, Plantago lanceolata, and Veronica chamaedrys. From the vulnerable species, only
Cyanus segetum was found in two meadows, but merely on the very edge of the parcel.

The communities of the fourth group were among the most species-rich communities in our territory. The average number of species was 45 , hence 66 species per relevé was the highest number. These communities were classified to the association Alchemillo-Arrhenatherion elatioris. A high abundance of the typical species of the alliance Arrhenatherion elatioris is characteristic for this vegetation type. Arrhenatherum elatius, Dactylis glomerata, Festuca pratensis, Festuca rubra and Poa pratensis were typically present. In early spring, Primula veris dominated in the vegetation. During summer, the colourful aspect was formed mainly by herbs Tragopogon orientalis, Salvia pratensis, Dianthus carthusianorum, Leucanthemum vulgare, Crepis biennis and Campanula patula. In the hierarchical system of syntaxa, this association is transitional between Pastinaco sativae-Arrhenatheretum elatioris and Anthoxantho odorati-Agrostietum tenuis.

Mesophilous meadows from the fifth group were mainly located in orchards, sites along streams, and on moderate slopes with deeper soil. Due to a sufficiency of nutrients and moisture, the vegetation was tall and dense, grasses prevailed - Arrhenatherum elatius, Dactylis glomerata, Trisetum flavescens, Festuca pratensis, Poa pratensis. However, Arrhenatherum elatius dominated. The average number of species was 42 . In many cases the vegetation of this group could be classified as transitional stages between the associations Pastinaco sativae-Arrhenatheretum elatioris and Alchemillo-Arrhenatherion elatioris. Some of the communities within this group were closely related to the association Poo-Trisetetum flavescentis. Most of the sites, however, were abandoned, so the vegetation was at a higher stage of succession with the presence of shrub and tree species.

The association Anthoxantho odorati-Agrostietum tenuis represents rich, once-mowed meadows or extensively used pastures, with 44 species per relevé on average, which also assign them to the grassland communities with high species diversity. They mostly occurred in the near vicinity of rural settlements on slight slopes at higher altitude. Relevés of this type of vegetation were negatively correlated to nutrient content. The vegetation consists of middle high or low grasses Festuca rubra, Briza media, from graminoids Luzula campestris and Luzula luzuloides. Presence of the species of the alliance Violion caninae was typical for this association. Species Viola canina, Luzula campestris, Polygala vulgaris, Veronica officinalis and Nardus stricta had higher frequency of occurrence. Five of the recorded meadows were abandoned. Due to the lack of management at these places, the ingrowths of high grasses such as Arrhenatherum elatius, Dactylis glomerata and 
Brachypodium pinnatum was very common. Threatened and protected species are often present in this association. In our case, nine of the relevés from this group contained rare species - Aquilegia vulgaris, Convallaria majalis, Crepis praemorsa, Dactylorhiza fuchsii, Dactylorhiza sambucina, Gymnadenia conopsea and Orchis morio.

Communities of the alliance Bromion erecti were relatively species-rich (on average 43 species per relevé). In comparison to the rest of the data set, this unit included the vegetation of warm and dry stands. At some of the sites, the vegetation consisted of two layers: tall grasses (Avenella flexuos, Avenula pubescens, Brachypodium pinnatum, Arrhenatherum elatius), short caespitose grasses and graminoid species (Carex caryophyllea, Carex montana and Carex pilulifera). Xerophilic species (Anthyllis vulneraria, Potentilla alba, Teucrium chamaedrys, Potentilla rupestris), mesophilic (Leucanthemum vulgare) and hygrophilic herbs (Betonica officinalis) were present as well. Communities of this group were close to the association Brachypodio pinnati-Molinietum arundinaceae. At some sites we could distinguish a variant with Potentilla erecta with constant species Anthoxanthum odoratum, Briza media, Hypericum perforatum, Potentilla erecta, Thlaspi monatnum, and Orchis morio. At acid soil, we recorded transitions towards the association of Campanulo rotundifoliae- $\mathrm{Di}$ anthetum deltoidis (alliance Violion caninae) with species Veronica officinalis, Viola canina, Potentilla erecta, Nardus stricta. High grasses dominated at locations without any management. Self-seeded trees (Acer campestre, Carpinus betulus, Crataegus monogyna) and species of warm herb fringe communities (Geranium sanguineum, Trifolium alpestre, Trifolium montanum and the threatened Lychnis coronaria) penetrated into the vegetation. In some cases, transitional forms towards the associations of Ranunculo bulbosi-Arrhenatheretum elatioris and Onobrychido viciifoliae-Brometum erecti could be recognised.

Grassland communities represented by the strongly dominant Bromus erectus, situated on dry or mesic sites, were classified as the association Onobrychido viciifoliae-Brometum erecti from the alliance of Bromion erecti. Some other subdominant grasses such as Avenula pubescens, Dactylis glomerata, Festuca rubra occurred in higher constancy. Regularly managed sites were especially rich in flowering plants. The number of species ranged between 37 and 60 (48 species on average). Beside the typical thermophilous species Dianthus carthusianorum, Pimpinella saxifraga, Ranunculus bulbosus, Salvia pratensis, Sanguisorba minor, Securigera varia, Teucrium chamaedrys, some mesophilous species were also present (Linum catharticum, Tragopogon orientalis, Veronica chamaedrys). In two cases, we can consider the mesophilic variant of the association with Leucanthemum vulgare, which differs in the presence of the species from alliance Arrhenaterion elatioris (e.g. Acetosa pratensis, Anthoxanthum odoratum, Campanula patula, Crepis biennis, Leucanthemum vulgare, Tragopogon orientalis, Trifolium pratense, Trisetum flavescens). In addition, orchids also frequently occurred here (Dactylorhiza sambucina, Gymnadenia conopsea).

The threatened, rare and protected taxa of Slovakia occurred at some sites as well. The most endangered species recorded at our sites were Orobanche elatior (Critically Endangered CR) and Thlaspi montanum (Vulnerable VU). We recorded six less vulnerable species belonging to the category Least Concern (LC; Aquilegia vulgaris, Centaurium erythraea, Convallaria majalis, Cyanus segetum, Gymnadenia conopsea, Lychnis coronaria) and nine species of the category Near Threatened (NT; Anemone sylvestris, Crepis praemorsa, Lilium bulbiferum, Dactylorhiza fuhcsii, Dactylorhiza majalis, Dactylorhiza sambucina, Orchis morio, Potentilla rupestris, Saxifraga granulata). Nine of the above mentioned threatened species are protected by law in the Slovak Republic - Gymnadenia conopsea, Lychnis coronaria, Lilium bulbiferum, Dactylorhiza fuhcsii, Dactylorhiza majalis, Dactylorhiza sambucina, Orchis morio, Potentilla rupestris and Thlaspi montanum.

\section{Discussion and conclusions}

Grasslands in the temperate zone of Europe, in comparison to other communities, are noted for their rich flora and high diversity (Pärtel et al. 1996, Šeffer et al. 2002). Among the communities with the highest species diversity are those of the Czech Republic and Slovakia, especially in the Biele Karpaty mountains, with 103 species per $24 \mathrm{~m}^{2}$ (Klimeš 1997) or even 105 species per $16 \mathrm{~m}^{2}$ in the National Nature Reserve of Čertoryje (Merunková et al. 2012). Chytrý et al. (2015) and Vadel (2015) claim the Slovenský raj National Park to have the species richest grassland communities. Due to the fact that the above mentioned areas are mainly situated on limestone bedrock, we expected lower species richness in Hodrušská hornatina highland because of the geological substrate that is mostly andezite. This was confirmed as we have recorded lower species richness - it ranged from 16 to 66 taxa per $25 \mathrm{~m}^{2}$. However, some of our sites were situated on limestone bedrock, where the number of species reached 60 or even 66 species. Ružičková \& Halada (2005) also found species-rich orchard meadows in Štiavnické vrchy mountains. But they were mainly of the other associations; Poo-Trisetetum flavescentis with the average number of 41 species (36-50) and the association Ranunculo bulbosi-Arrhenateretum elatioris, with 47 species on average (39-58). Some mesophilous mead- 
ows from the alliance Arrhenatherion elatioris (the fifth group of our relevés) were closely related to these two associations.

Out of 153 phytosociological relevés, we determined five associations and two groups of higher syntaxa: Molinio-Arrhenatheretea and Festuco-Brometea classes. Holcetum lanati occurs probably in the whole of temperate Europe, but its distribution has not been very well documented yet (Stančić 2008). From Central Slovakia, Kováčová (1976) states its occurrence on the alluvium of the Krupinica river. The majority of our relevés include communities from the alliance Arrhenatherion elatioris. This alliance is widely distributed over whole Europe, from the north - Scandinavia (Dierssen 1996), through Central Europe to the south - the Balkans (Stančić 2008, Velev et al. 2011, Velev \& Vassilev 2014). In Slovakia, these communities are very frequent in uplands and submountain regions (Janišová et al. 2007). In our research area, the association Pastinaco sativae-Arrhenatheretum elatioris was the most common. According to Hájková et al. (2014), it can be found almost in the whole area of Slovakia, but mainly in uplands and the inner basins of the Slovak Carpathians because the lowland localities were ploughed up or intensified. There are also some unpublished records of Ružičková from the Štiavnické vrchy mountains (Hájková et al. 2014). The association Alchemillo-Arrhenatheretum elatioris is mainly distributed on the volcanic or limestone bedrock of the central and western parts of Slovakia, including the Štiavnické vrchy mountains (Ružičková \& Halada 2005, Banásová et al. 2006). The association Anthoxantho odorati-Agrostietum tenuis is not a rare community either. It occurs on shallower and more acidic soil, almost in the whole Carpathian region of Slovakia (Janišová et al. 2010b). Ružičková (1986) and Ružičková \& Halada (2005) stated its occurrence in the Štiavnické vrchy mountains. The western part of Central Europe (France, Great Britain, Denmark, even the south of Sweden) is a centre of the occurrence of Bromion erecti (Chytrý et al., 2007). Communities of this alliance in the subcontinental climate are known from the Czech Republic (Chytrý et al. 2007), Hungary (Borhidi \& Sánta 1999) and Slovakia (Hegedüšová Vantarová \& Škodová 2014). According to Janišová et al. (2010b), the associations of this alliance represent the most frequent semi-dry grasslands in Central Slovakia. In the past, these communities were regularly mown. The two associations within this alliance do not differ much. This type of vegetation represents the transition stage towards the association of Ranunculo bulbosi-Arrhenatheretum elatioris (Škodová 2007). Ružičková \& Halada (2005) stated that Onobrychido viciifoliae-Brometum erecti occurred also in the Štiavnické vrchy mountains.
According to the actual Red List of plant species of Slovakia (Eliáš et al. 2015) we identified 17 species listed in IUCN categories. The critically endangered Orobanche elatior is a taxon with not enough data on its occurrence within Slovakia (Eliáš et al. 2015). However, in older literature, it is considered as a rare taxon in the studied area, mainly in the south-east of the territory (Hlavaček 1985). At grasslands in Hodrušská hornatina highland, Orchis morio was the most frequent of threatened species. Salenka (2012) and Slezák et al. (2012) also reported this species from several locations in the territory (e.g. Vyhne village). The occurrence of thermophilic species Lychnis coronaria is stated from warmer parts of our studied area (Hlavaček 1985, Tóthová 2014). Species Aquilegia vulgaris, Dactylorbiza sambucina, Gymnadenia conopsea and Saxifraga granulata could be classified as more abundant in Hodrušská hornatina highlands (Futák et al. 1982, Bertová et al. 1985, Salenka 2012, Slezák et al. 2012).

The highest number of threatened species (15 species) was found in the association Anthoxantho odorati-Agrostietum tenuis. Also according to Uhliarová et al. (2014), threatened and protected species are often present in this association. We can also claim this association as the most vulnerable. Because of its occurrence on sites with higher altitude, it is most likely to be abandoned. Dry grasslands of the alliance of Bromion erecti have to face many threats, either. First of all, the abandonment causes successional changes in species composition as well as expansion of tall grasses and shrub. For maintaining the vegetation type in proper condition we would recommend the rotation of regular pasture and mowing.

Although the area of Hodrušská hornatina highland is mostly covered by forest vegetation, many valuable semi-natural grasslands can be found here. There are meadows, pastures and also orchard meadows, which are typical for the historical cultural landscape in Slovakia. Grasslands are very important to people for different reasons (agriculture, landscape-aesthetic value, recreation). Some of them are important in maintaining the vulnerable and threatened species. The floristic and vegetation composition is a result of a complex influence of many environment variables (Škodová et al. 2011) as well as of the site history, age, and traditional type of management practices (Pärtel et al. 1996, Hájková et al. 2011). The structure and the species composition depend on the ecological conditions, particularly the light, nutrient content and water regime. As our research showed, suitable management is an especially important factor in maintaining grassland communities. However, people are consistently losing their interest in farming. Every year, there are more and more abandoned meadows, which are gradually changing towards forests. There are still some 
meadows with traditional agricultural management, but we think the situation with their long-term maintenance is not very promising. It is necessary to continue with the management activities or find alternatives to traditional farming and utilization of meadows.

\section{Acknowledgement}

The author is grateful to the Slovak Grant Agency VEGA, project No. 2/0117/13 for financial support.

\section{References}

Aćić, S., Šilc, U., Petrović, M., Tomović, G. \& Dajić Stevanović, Z. 2015: Classification, ecology and biodiversity of Central Balkan dry grasslands. Tuexenia 35: 329-353.

Banásová, V., Horak, O., Čiamporová, M., Nadubinská, M. \& Lichtschneidl, I. 2006: The vegetation of metalliferous and nonmetalliferous grasslands in two former mine regions in Centra Slovakia. Biologia 61 (4): 433-439.

Bertová, L. (ed.). 1985: Flóra Slovenska IV/2. Veda, Bratislava, 324 pp.

Blažková, D. \& Březina, S. 2003: Secondary succession in abandoned "poloniny" meadows, Bukovské vrchy Mts., Eastern Carpathians, Slovakia. Thaiszia Journal of Botany 13: 159-207.

Borhidi, A. \& Sánta, A. (eds.). 1999: Vörös könyv Magyarország növénytársulásairól 1.-2. Természet BÚVÁR Alapítvány Kiadó, 766 pp.

Borhidi, A., Kevey, B. \& Lendvai, G. 2012: Plant communities of Hungary. Akadémiai Kiadó, 544 pp.

Botta-Dukát, Z., Chytrý, M., Hájková, P. \& Havlová, M. 2005: Vegetation of lowland wet meadows along a climatic continetality gradient in Central Europe. Preslia 77: 89-111.

Braun-Blanquet, J. 1930: Zentralalpen und Tatra, ein pflanzensoziologische Parallele. Veröff. Geobot. Inst., Zürich 6: 81-133.

Braun-Blanquet, J. 1964: Pflanzensoziologie. Grundzuge der Vegetationskunde. Ed. 3. Springer Verlag, Wien \& New York, 865 pp.

Chytrý, M. (ed.) 2007: Vegetace České Republiky 1. Travinná a keřícková vegetace. Academia, Praha, 526 pp.

Chytrý, M. \& Otýpková, Z. 2003: Plot size used for phytosociological sampling of European vegetation. Journal of Vegetation Science 14 (4): 563-570.

Chytrý, M., Dražil, T., Hájek, M., Kalníková, V., Preislerová, Z., Šibík, J., Ujházy, K., Axmanová, I., Bernátová, D., Blanár, D., Dančák,

M., Dřevojan, P., Fajmon, K., Galvánek, D., Hájková, P., Herben, T., Hrivnák, R., Janeček, Š., Janišová, M., Jiráska, Š., Kliment, J., Kochjarová, J., Leskovianska, A., Merunková, K., Mládek, J., Slezák, M., Šeffer, J., Šefferová, V., Škodová, I., Uhlíŕová, J., Ujházyová, M. \& Vymazalová, M. 2015: The most species-rich plant communities of the Czech Republic and Slovakia (with new world records). Preslia 87: 217-278.
Chytrý, M., Tichý, L., Holt, J. \& Botta-Dukát, Z. 2002:

Determination of diagnostic species with statistical fidelity measures. Journal of Vegetation Science 13: 79-90.

Dierssen, K. 1996: Vegetation Nordeuropas. Eugen Ulmer, 838 pp.

Ellenberg, H., Weber, H. E., Düll, R., Wirth, V., Erner, W. \& Paulissen, D. 1992: Zeigwerte von Pflanzen in Mitteleuropa. Scripta Geobotanica. Erich Goltze, Göttingen, 258 pp.

Eliáš, P., Dítě, D., Kliment, J., Hrivnák, R. \& Feráková, V. 2015: Red list of ferns and flowering plants of Slovakia, $5^{\text {th }}$ edition. Biologia 70 (2): 218-228.

Futák, J. 1943: Kremnické vrchy. Geobotanická a floristická štúdia. Matica Slovenská, Turč. Sv. Martin, 112 pp.

Futák, J. 1947: Xerotermná vegetácia PR Kňažný stôl. Sp. Sv. Vojtecha, Trnkava, $258 \mathrm{pp}$.

Futák, J.(ed). 1966: Flóra Slovenska II. Veda, Bratislava, 349 pp.

Futák, J. (ed.). 1982: Flóra Slovenska III. Veda, Bratislava, 608 pp.

Galvánek, D. \& Viestová, E. 2006: Lúky Slovenska. Príručka rozumného hospodárenia. Bratislava: DAPHNE - Inštitút aplikovanej ekológie, 16 pp.

Hájková P., Hájek M. \& Smatanová J. 2001: Nelesná vegetácia mokradí Strážovských vrchov. Ochr. Prír. 19: 25-46.

Hájková, P., Roleček, J. , Hájek, M., Horsák, M., Fajmon, K., Polák, M. \& Jamrichová, E. 2011: Prehistoric origin of the extremely speciesrich semi-dry grasslands in the Bílé Karpaty Mts (Czech Republic and Slovakia). Preslia 83: 185-204.

Hájková, P., Zaliberová, M. \& Uhliarová, E. 2014: MolinioArrhenatheretea. In: Hegedüšová Vantarová, K. \& Škodová, I. (eds.) 2014: Vegetácia Slovenska. Rastlinné spoločenstvá Slovenska 5. Travinno-bylinná vegetácia. Veda, pp. 194-201.

Hegedüšová, K. \& Ružičková, H. 2007: Diversity of alliance PolygonoTrisetion and its occurrence in Slovakia. In: Ecology of grassland comminuities VII. Zborník prác zo VII. Medzinárodnej konferencie pri príležitosti 45. výročia vzniku Výskumného ústavu trávnych porastov a horského polnohospodárstva a životného jubilee prof. Ing. Vladimíra Krajčoviča, 28. - 30.11.2007. Banská Bystrica, 146-153.

Hegedüšová, K., Ružičková, H., Senko, D. \& Zuccarini, P. 2011: Plant communities of the montane mesophilous grasslands (Polygono bistortae-Trisetion flavescentis alliance) in central Europe: Formalized classification and syntaxonomical revision. Plant Biosystems 145 (1): 1-16.

Hegedüšová Vantarová, K. \& Škodová, I. (eds.) 2014: Vegetácia Slovenska. Rastlinné spoločenstvá Slovenska 5. Travinno-bylinná vegetácia. Veda1 581 pp.

Hennekens, S. \& Schaminée, J. H. J. 2001: TURBOVEG a comprehensive data base management for vegetation data. Journal of Vegetation Science 12 (4): 589-591.

Hill, M. O., 1979: Twinspan. A fortran program for arranging multivariate data in an ordered two - way table by classification of the individuals and attributes. Ecology and Systematics, Cornell University, Ithaca, New York.

Hlavaček, A., 1985: Flóra chránenej krajinnej oblasti Štiavnické vrchy. Ústredie štátnej ochrany prírody. Liptovský Mikuláš. 774 pp. 
Janišová, M., Hájková, P., Hegedüšová, K., Hrivnák, R., Kliment, J., Michálková, D., Ružičková, H., Řezníčková, M., Tichý, L., Škodová, I., Uhliarová, E., Ujházy, K. \& Zaliberová, M. 2007: Grassland vegetation of Slovakia - electronical expert system for syntaxa identification. Botanický ústav SAV, Bratislava, 263 pp.

Janišová, M., Uhliarová, E., Hlásny, T. \& Turisová, I. 2010a: Vegetation-environment relationship in grassland communities of central Slovakia. Tuexenia 33: 426-444.

Janišová, M., Uhliarová, E. \& Ružičková, H. 2010b: Expert systembased classification of semi-natural grasslands in submontane and montane regions of central Slovakia. Tuexenia 30: 375-422.

Jurko, A. 1951: Vegetácia stredného Pohornádia. Vydavatel'stvo SAV, Bratislava, 105 pp.

Jurko, A. 1974: Prodromus der Cynosurion-Gesselshaften in den Westkarpaten. Folia Geobotanica et Phytotaxonomica 9: 1-44.

Klimeš, L. 1997: Druhová bohatost' lúk v pohorí Bíle Karpaty. Sborník Př́rodovědeckého klubu v Uherském Hradišti 2: 31-42.

Kováčová, M. 1976: Association of Holcetum lanati (Issler 1936) em. Passarge 1964 v alúviu rieky Krupinica. Biológia 31: 795-800.

Kukk, T. \& Kull, K. 1997: Puisniidud (Wooded meadows). Estonia Maritima $2: 1-249$.

Kull, K. \& Zobel, M. 1991: High species richness in Estonian wooded meadows. Journal of Vegetation Science 2: 711-714.

Kunca, V., Šeffek, J., Olah, B., Gavlas, V. \& Wiezik, M. 2005: Dynamika ekosystémov v Štiavnických vrchoch 102 pp.

Marhold, K. \& Hindák, F. 1998: Zoznam nižších a vyšších rastlín Slovenska. VEDA, Bratislava, $687 \mathrm{pp}$.

Májovský, J. 1953: Geobotanické pomery Kapušianskych kopcov (okres Prešov). Biologia 9: 144-165.

Merunková, K., Preislerova, Z. \& Chytrý, M. 2012: White Carpathian grasslands: can local ecological factors explain their extraordinary species richness? Preslia 84: 311-325.

Michálková-Dúbravková, D., Janišová, M., Kolbek, J., Šuvada, R., Virók, V. \& Zaliberová, M. 2007: Dry grasslands in the Slovenský kras Mts. (Slovakia) and the Aggteleki-karszt Mts. (Hungary) - a comparison of two classification approaches. Hacquetia 7 (2): 123-140.

Miklós, L. \& Izakovičová, Z. (eds.) 2006: The Atlas of Slovak representative geo-ecosystems. Esprit, Banská Štiavnica, 124 pp.

Miklós, L. \& Hrnčiarová, T. (eds.) 2002: The Atlas of the Slovak Republic landscape. Bratislava, Ministerstvo životného prostredia, $342 \mathrm{pp}$.

Moog, D., Poschlod, P., Kahmen, S. \& Schreiber, K.-F. 2002: Comparison of species composition between different grassland management treatments after 25 years. Applied Vegetation Science 5: 99-106.

Mucina, L., Grabherr, G. \& Ellmauer, T. (eds.): Die Pflanzengesellschaften Österreichs. Teil I. Gustav Fischer Verlag, Jena, 578 pp.

Novák, J. 2008: Pasienky, lúky a trávne porasty. Prievidza: Patria I. spol. s r. o., 708 pp.
Novák, J. 2009: Trávne porasty po odlesnení a samozalesnení. Nitra. 165 pp.

Parker, K.C. 1988: Environmental relationship and vegetation associates of columnar cacti in the northern Sonoran Desert. Vegetatio 78:125-140.

Pärtel, M., Zobel, M., Zobel, K. \& van der Maarel, E. 1996: The species pool and its relation to species richness: evidence from Estonian plant communities. Oikos 75:111-117.

Ružičková, H. 1986: Bezkolencové lúky (association Junco-Molinietum Preising 1951) at Holý vrch. In: Šteffek J. (ed.) Zborník XXI.TOPu. Počúvadlo, p. 5-13.

Ružičková, H. 2002: Species-rich meadows of the Starohorské vrchy Mts. and the southeastern part of the Vel'ká Fatra Mts. - relict of the extensive and semiintensive agriculture of the Central Western Carpatians. Biologia 57(4): 493-504.

Ružičková, H. \& Halada, L. 2005: Orchard meadows of Banská Štiavnica town (Central Slovakia). Polish Bot. Stud. 19: 211-218.

Ružičková, H. \& Kalivoda, H. 2007: Kvetnaté lúky - Národné bohatstvo Slovenska. Bratislava: Veda, vydavatel'stvo SAV, 2007. 136 pp.

Ružičková, H., Škodová, I. \& Janák, M. 2011: Manažmentové modely pre mesofilné lúky. (all. Arrhenatherion elatioris). Daphne - Inštitút aplikovanej ekológie, Bratislava, $28 \mathrm{pp}$.

Salenka, P. 2012: Katastrálne územie obce Vyhne - významné územie vstavačovitých

rastlín v Štiavnických vrchoch. Bulletin Slovenskej botanickej spoločnosti 34: 1 65-73.

Sammul, M., Kull, K. \& Tamm, A. 2003: Clonal growth in a speciesrich grassland: results of 20-year fertilization experiment. Folia Geobotanica 38 (1): 1-20.

SHMÚ 2015: Atlas of Climate. Slovak hydro-meteorological institute. Online: http://klimat.shmu.sk/kas/ [11.9.2015].

Slezák, M., Letz, R. D., Hrivnák, R., Vlčko, J., Turis, P. \& Blanár, D. 2012: Aktuálne poznatky o výskyte niektorých zriedkavejších cievnatých rastlín na území stredného Slovenska. Bulletin Slovenskej Botanickej Spoločnosti, 34 (1): 19-44.

Stančić, Z. 2008: Classification of mesic and wet grasslands in northwest Croatia. Biologia 63 (6): 1089-1103.

Šeffer, J., Lasák, R., Galvánek, D. \& Stanová, V., 2002: Grasslands of Slovakia - Final Report on National Grassland Inventory 1998-2002, DAPHNE, Bratislava. 112 pp.

Škodová, I. 2007: Bromion erecti Koch 1926. In: Janišová M. (ed.), 2007: Travinnobylinná vegetácia Slovenska - elektronický expertný systém na identifikáciu taxónov. Botanický ústav SAV. 71-77.

Škodová, I., Devánová, K. \& Senko, D. 2011. Subxerophilous and mesophilous grasslands of the Biele Karpaty Mts. (White Carpathian Mts.) in Slovakia. Tuexenia 31: 235-269.

Tasser, E. \& Tappeiner, U. 2002: Impact of land use changes on mountain vegetation. Applied Vegetation Science 5: 173-184.

ter Braak, C. J. F. \& Šmilauer, P. 2002: CANOCO. Reference Manual and CanoDraw for Windows User's Guide: Software for Canonical 
Community Ordination (version 4.5). Microcomputer Power (Ithaca NY, USA), 500 pp.

Tichý, L. 2002: JUICE, software for vegetation classification. Journal of Vegetation Science 13: 451-453.

Tóthová, A. 2014. Floristic Properties of Meadows in the Cadastre of Hodruša - Hámre Village in Štiavnické vrchy Mountains. In: Scientia iuvenis: Book of Scientific Papers / editor Michal Hudec, Antal Csáky. CPU. Nitra. p. 151-156.

Uhliarová, Janišová, M. \& Ujházy, K. 2007: Arrhenatherion elatioris Luquet 1926. In: Janišová M. (ed.), 2007: Travinnobylinná vegetácia Slovenska - elektronický expertný systém na identifikáciu taxónov. Botanický ústav SAV, p. 91-109.

Uhliarová, Janišová, M., Ujházy, K. Škodová, I. \& Hájek, M. 2014: Arrhenatherion elatioris Luquet 1926. In: Hegedüšová Vantarová, K. \& Škodová, I. (eds.) 2014: Vegetácia Slovenska. Rastlinné spoločenstvá Slovenska 5. Travinno-bylinná vegetácia, Veda, p. 202-239.
Vadel, L. 2015: Synekologická charakteristika vegetácie Kopanických lúk v Národnom parku Slovenský Raj. Dizertačná práca, UKF Nitra, 143 pp.

van der Maarel, E. 1979: Transformation of cover-abundance values in phytosociology and its effect on community similarity. Vegetatio 39: 97-114.

Velev, N., Apostolova, I. \& Rozbrojová, Z. 2011: Alliance Arrhenatherion elatioris in West Bulgaria. Phytologia Balcanica 17 (1): 67-78.

Velev, N. \& Vassilev, K. 2014 Management regimes within syntaxa of semi-natural grasslands in west Bulgaria. Hacquetia 13 (1): 191-204.

Table 1: Shortened synoptic table of studied plant communities.

Tabela 1: Skrajšana sinoptična tabela preučevanih rastlinskih združb

$\begin{array}{lllllllll}\text { Group No. } & 1 & 2 & 3 & 4 & 5 & 6 & 7 & 8 \\ \text { No. of relevés } & 9 & 5 & 32 & 27 & 33 & 30 & 12 & 5\end{array}$

\section{Association Holcetum lanati}

Cardamine pratensis

Lysimachia nummularia

Equisetum arvense

Lychnis flos-cuculi

$\begin{array}{ccc}67^{71.2} & \cdot & 6 \\ 44^{59.1} & \cdot & 6 \\ 56^{48.6} & 40 & 6 \\ 67^{37.1} & 80 & 28\end{array}$

Association Pastinaco sativae-Arrhenatheretum elatioris-intensive meadows

Symphytum officinale

Cirsium oleraceum

Rumex obtusifolius

Stellaria media

Carduus personata

Plantag omajor

Association Pastinaco sativae-Arrhenatheretum elatioris

Veronica chamaedrys

Association Alchemillo-Arrhenatheretum elatioris

Vicia hirsuta

Lathyrus pratensis

$\begin{array}{cc}\text {. } & 60^{73.1} \\ \cdot & 40^{60.7} \\ \cdot & 40^{60.7} \\ \cdot & 40^{60.7} \\ . & 40^{60.7} \\ 56 & 80^{52.5}\end{array}$

Centaurea phrygia

Association Alchemillo-Arrbenatheretum elatioris

Primula veris

Salvia pratensis

Plantago media

Dianthus carthusianorum

Association Anthoxantho odorati-Agrostietum tenuis

Hieracium cymosum

Potentilla erecta

Genista tinctoria

Polygala vulgaris

$\begin{array}{cccccccc}11 & . & 9 & 7 & 39^{32.5} & 27 & . & \\ 11 & . & 16 & 63 & 76^{26.6} & 13 & 50 & 100 \\ 44 & . & 9 & 48 & 61^{24.9} & 23 & 17 & 40 \\ . & . & 16 & 48 & 82^{24.0} & 80 & 75 & 100 \\ & & & & & & & \\ . & . & 3 & 4 & 15 & 50^{54.2} & . & \cdot \\ 22 & . & 3 & 11 & 18 & 67^{47.3} & 25 & . \\ . & . & . & . & 18 & 40^{43.4} & 8 & . \\ . & . & 3 & 7 & 21 & 70^{41.7} & 25 & 60\end{array}$




\begin{tabular}{|c|c|c|c|c|c|c|c|c|}
\hline Group No. & 1 & 2 & 3 & 4 & 5 & 6 & 7 & 8 \\
\hline No. of relevés & 9 & 5 & 32 & 27 & 33 & 30 & 12 & 5 \\
\hline Hypochaeris radicata & 11 & . & 6 & . & 15 & $33^{34.5}$ & & . \\
\hline Viola canina & 22 & . & 16 & 15 & 24 & $60^{34.2}$ & 42 & . \\
\hline Thymus pulegioides & . & . & 9 & 30 & 39 & $73^{33.2}$ & 67 & 40 \\
\hline Briza media & 11 & . & 19 & 33 & 64 & $83^{32.8}$ & 75 & 40 \\
\hline Hieracium pilosella & . & . & . & 15 & 15 & $53^{32.8}$ & 50 & 20 \\
\hline Luzula campestris & 56 & . & 59 & 63 & 67 & $97^{29.6}$ & 83 & 40 \\
\hline Veronica serpyllifolia & 22 & . & 9 & 7 & 9 & $33^{28.9}$ & . & . \\
\hline Cruciata glabra & 56 & . & 47 & 70 & 52 & $83^{27.4}$ & 50 & 20 \\
\hline Veronica officinalis & . & . & . & 11 & 3 & $33^{23.6}$ & 33 & 20 \\
\hline \multicolumn{9}{|l|}{ Alliance Bromion erecti } \\
\hline Geranium sanguineum & . & . & 3 & 4 & 6 & 7 & $67^{59.5}$ & 20 \\
\hline Avenella flexuosa & . & . & . & 4 & . & . & $42^{58.8}$ & . \\
\hline Campanula persicifolia & . & . & . & 4 & 9 & 3 & $42^{50.3}$ & . \\
\hline Trifolium alpestre & 11 & . & 16 & 7 & 18 & 20 & $75^{50.3}$ & 20 \\
\hline Silene nutans s.lat. & . & . & . & 4 & 9 & 10 & $42^{46.7}$ & . \\
\hline Brachypodium pinnatum & . & . & 3 & . & 6 & 7 & $42^{40.9}$ & 20 \\
\hline \multicolumn{9}{|c|}{ Association Onobrychido viciifoliae- Brometum erecti } \\
\hline Bromus erectus & . & 20 & 9 & . & 3 & . & 25 & $100^{76.4}$ \\
\hline Campanula rapunculoides & . & . & . & 7 & . & . & . & $60^{70.2}$ \\
\hline Linum catharticum & . & . & 3 & 4 & 12 & 10 & 8 & $80^{69.8}$ \\
\hline Medicago falcata & . & . & 3 & 7 & . & . & . & $60^{68.2}$ \\
\hline Securigera varia & . & . & . & 4 & . & . & 8 & $60^{67.3}$ \\
\hline Primula elatior & . & . & 9 & 15 & 3 & 3 & 25 & $80^{63.5}$ \\
\hline Ranunculus bulbosus & 11 & & 19 & 4 & 12 & 27 & 42 & $100^{62.5}$ \\
\hline Medicago lupulina & . & 20 & 19 & . & 15 & 3 & 8 & $80^{60.5}$ \\
\hline Sanguisorba minor & . & . & 3 & 11 & 18 & 3 & 33 & $80^{59.6}$ \\
\hline Avenula pubescens & . & & 16 & 30 & 3 & 3 & 92 & $100^{57.2}$ \\
\hline
\end{tabular}


Table 2: Relevés of the association Holcetum lanati Issler 1936.

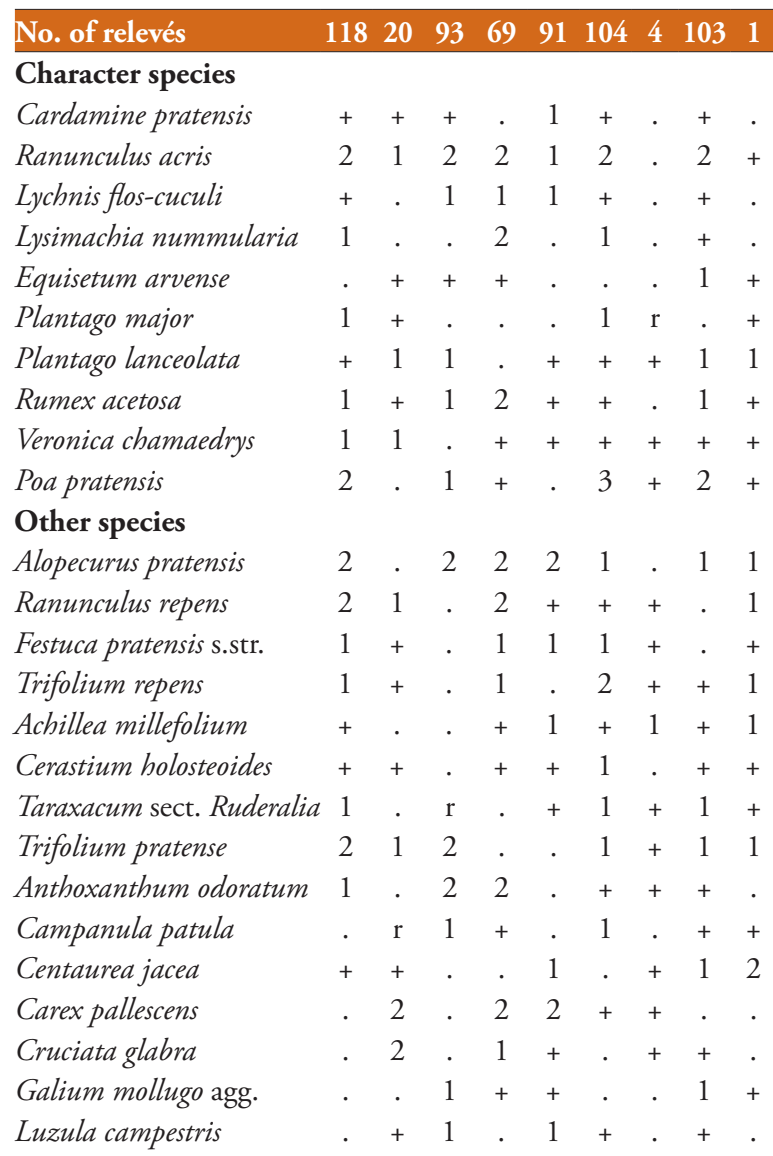

Tabela 2: Popisi asociacije Holcetum lanati Issler 1936.

\begin{tabular}{|c|c|c|c|c|c|c|c|c|c|}
\hline No. of relevés & 118 & 20 & 93 & 69 & 91 & 104 & 4 & 103 & 1 \\
\hline Leucanthemum vulgare & . & + & + & . & + & + & . & + & . \\
\hline Dactylis glomerata & 2 & . & . & . & + & . & + & 1 & + \\
\hline Carex muricata agg. & . & 2 & . & 1 & . & + & + & . & . \\
\hline Leontodon autumnalis & . & . & . & . & . & 2 & 1 & + & $\mathrm{r}$ \\
\hline Plantago media & . & . & . & . & . & $\mathrm{r}$ & + & 1 & $\mathrm{r}$ \\
\hline Leontodon hispidus & . & . & 1 & . & . & . & 1 & 1 & + \\
\hline Lotus corniculatus & + & . & . & . & . & . & 1 & + & + \\
\hline Holcus lanatus & 2 & 2 & . & . & . & . & . & . & + \\
\hline Myosotis arvensis & . & . & . & + & + & + & . & . & . \\
\hline Agrostis capillaris & . & . & . & + & . & . & + & . & + \\
\hline Poa compressa & + & . & . & . & 2 & 1 & . & . & . \\
\hline Cynosurus cristatus & . & . & . & . & 1 & 2 & + & . & . \\
\hline Trifolium campestre & + & . & + & . & + & . & . & . & . \\
\hline Potentilla reptans & + & . & + & . & + & . & . & . & . \\
\hline Agrimonia eupatoria & . & . & . & . & + & . & 1 & . & + \\
\hline Vicia tetrasperma & . & . & 1 & . & + & . & + & . & . \\
\hline Glechoma hederacea & 1 & . & . & . & . & + & . & . & + \\
\hline Stellaria graminea & + & + & . & . & . & + & . & . & . \\
\hline Rumex acetosella s.lat. & + & + & . & . & . & + & . & . & . \\
\hline Prunella vulgaris & . & . & . & . & . & + & + & . & + \\
\hline Arrhenatherum elatius & . & . & 1 & . & . & . & + & . & + \\
\hline Daucus carota & . & . & + & . & . & . & + & . & + \\
\hline Knautia arvensis & . & . & $\mathrm{r}$ & . & . & . & + & . & 1 \\
\hline Pimpinella saxifraga & . & + & . & . & . & . & + & 1 & . \\
\hline Crepis biennis & . & . & . & . & . & . & + & 1 & 1 \\
\hline Trisetum flavescens & 2 & . & 2 & . & . & . & . & 2 & . \\
\hline
\end{tabular}

Table 3: Relevés of the association Pastinaco sativae-Arrhenatheretum elatioris Passarge 1964 - intensively used meadows.

Tabela 3: Popisi asociacije Pastinaco sativae-Arrhenatheretum elatioris Passarge 1964 - intenzivno gospodarjena travišča.

\section{No. of relevés}

\section{Character species}

Carduus personata

Cirsium oleraceum

Plantago major

Rumex obtusifolius

Stellaria media

Symphytum officinale

Achillea millefolium

Alopecurus pratensis

Dactylis glomerata

Poa pratensis

Ranunculus acris

Taraxacum sect. Ruderalia

Trifolium pratense

Other species

Ranunculus repens

Arrhenatherum elatius

Trifolium repens

$\begin{array}{lllll}98 & 2 & 3 & 102 & 101\end{array}$ \\ $\begin{array}{lllll}98 & 2 & 3 & 102 & 101\end{array}$}

$\begin{array}{lllll}. & 1 & + & \cdot & . \\ . & 1 & \mathrm{r} & \cdot & . \\ 1 & 2 & 2 & . & + \\ . & 1 & 1 & . & . \\ . & . & . & + & + \\ . & 1 & 1 & . & 1 \\ 1 & 2 & 2 & + & 1 \\ 2 & 1 & 1 & 2 & + \\ 2 & 1 & 1 & + & 2 \\ 2 & 2 & 2 & 3 & 2 \\ + & + & + & 1 & 1 \\ 1 & 1 & 1 & 1 & + \\ 2 & 2 & 2 & 1 & 2\end{array}$

\begin{tabular}{lccccc}
\hline No. of relevés & 98 & 2 & 3 & 102 & 101 \\
\hline Deschampsia cespitosa & 1 & 2 & 2 &. & 2 \\
Agrimonia eupatoria &. & 1 & 1 & + & 1 \\
Plantago lanceolata & 1 & 2 & 2 &. & + \\
Lychnis flos-cuculi & + & + & + &. & + \\
Glechoma hederacea & 1 & 2 & 2 &. &. \\
Galium mollugo agg. &. & 1 & 1 & 2 &. \\
Anthriscus sylvestris &. & . & r & 1 &. \\
Centaurea jacea & 1 &. &. & 1 & 1 \\
Trisetum flavescens & 1 &. &. & 1 & + \\
Daucus carota &. & 1 & 1 &. & + \\
Veronica verna &. & + & + &. & + \\
Rumex acetosa & 1 &. & + &. &. \\
Veronica chamaedrys & 1 &. &. & 1 &. \\
Vicia sepium & + &. &. & + &. \\
Lathyrus pratensis &. & 2 & 2 &. &. \\
Equisetum arvense &. & 1 & 2 &. &. \\
Pimpinella saxifraga s.str. &. & 1 & 1 &. &. \\
\hline
\end{tabular}


Table 4: Relevés of the association Pastinaco sativae-Arrhenatheretum elatioris Passarge 1964.

Tabela 4: Popisi asociacije Pastinaco sativae-Arrhenatheretum elatioris Passarge 1964.

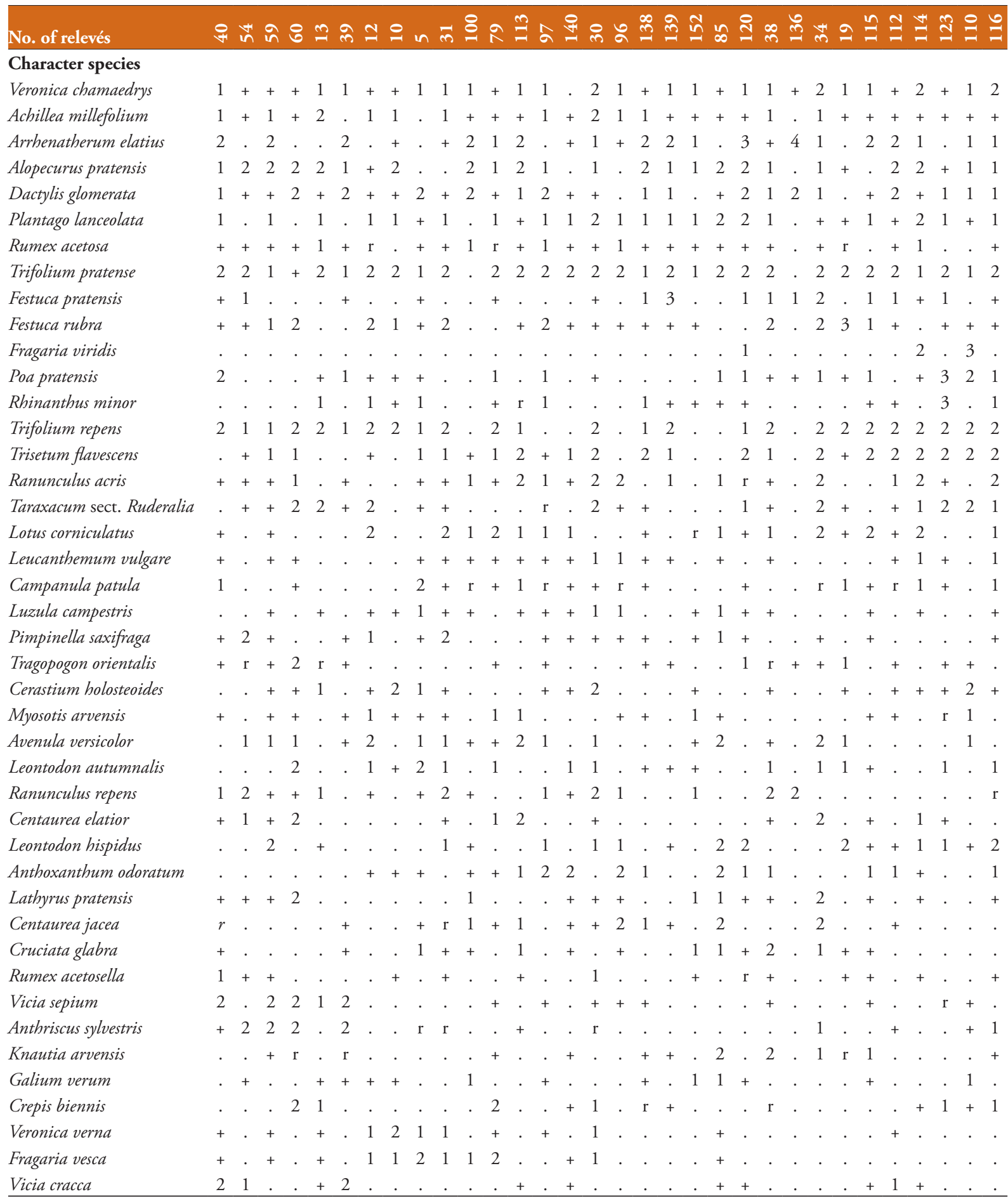




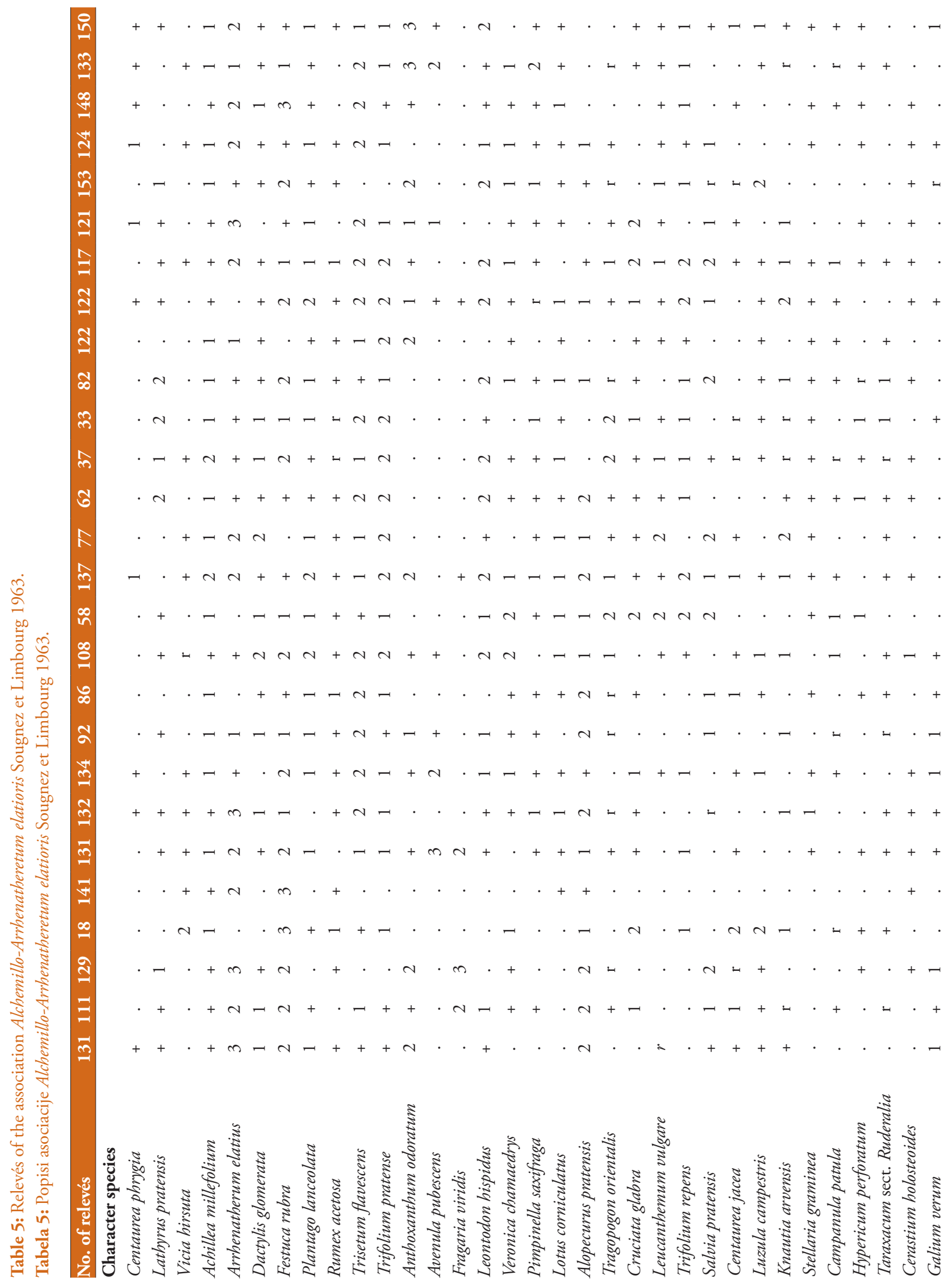




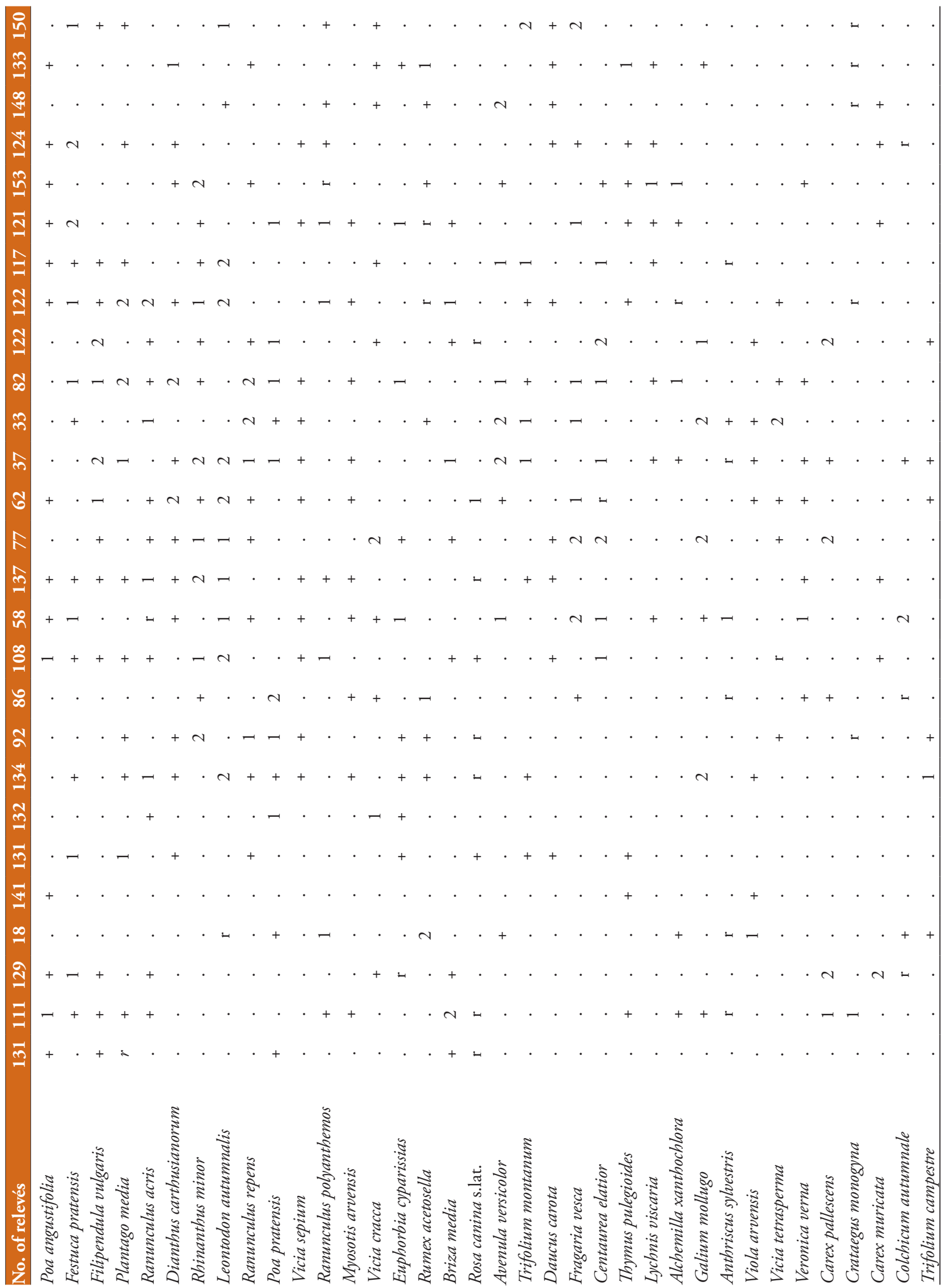




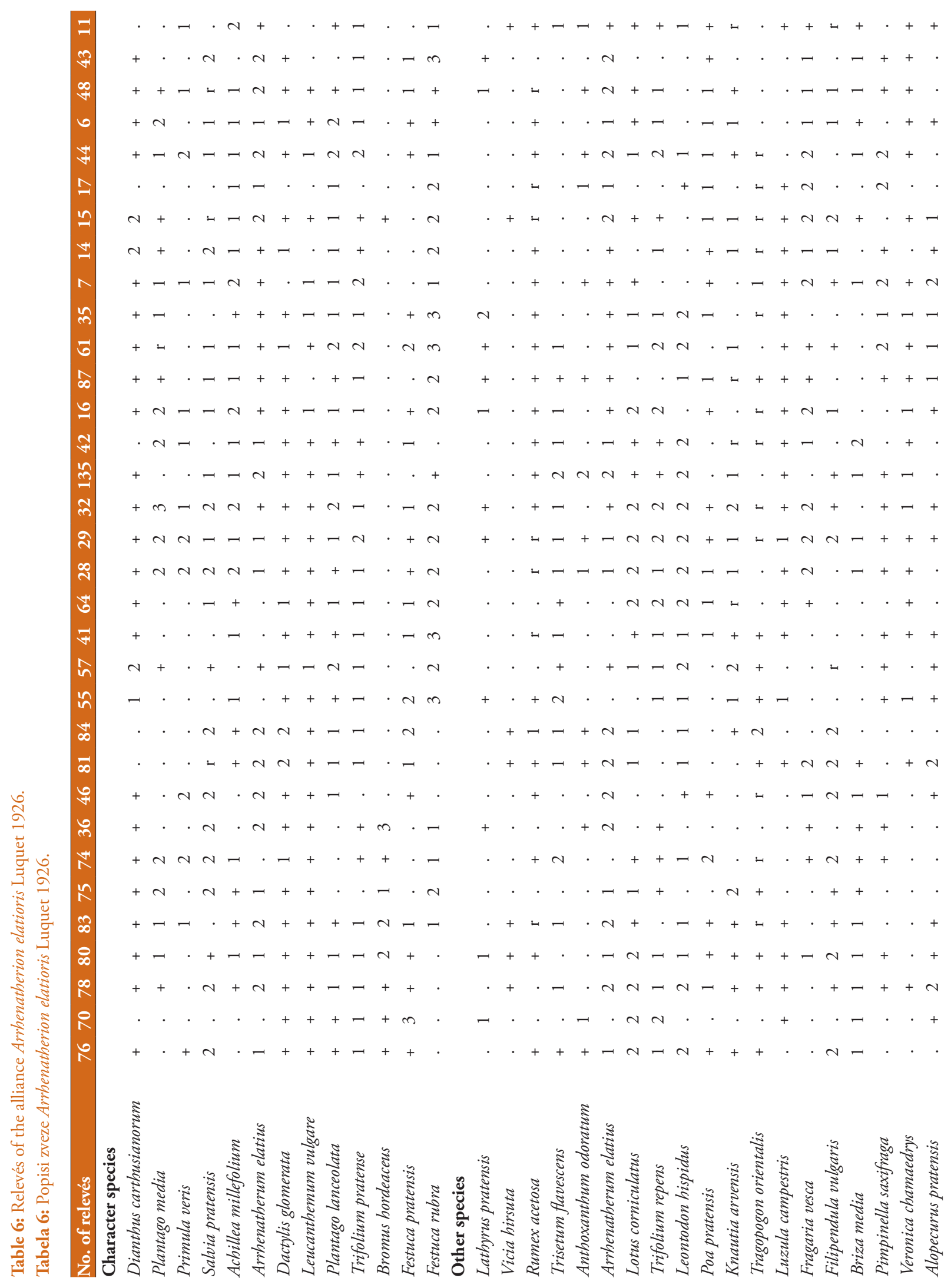




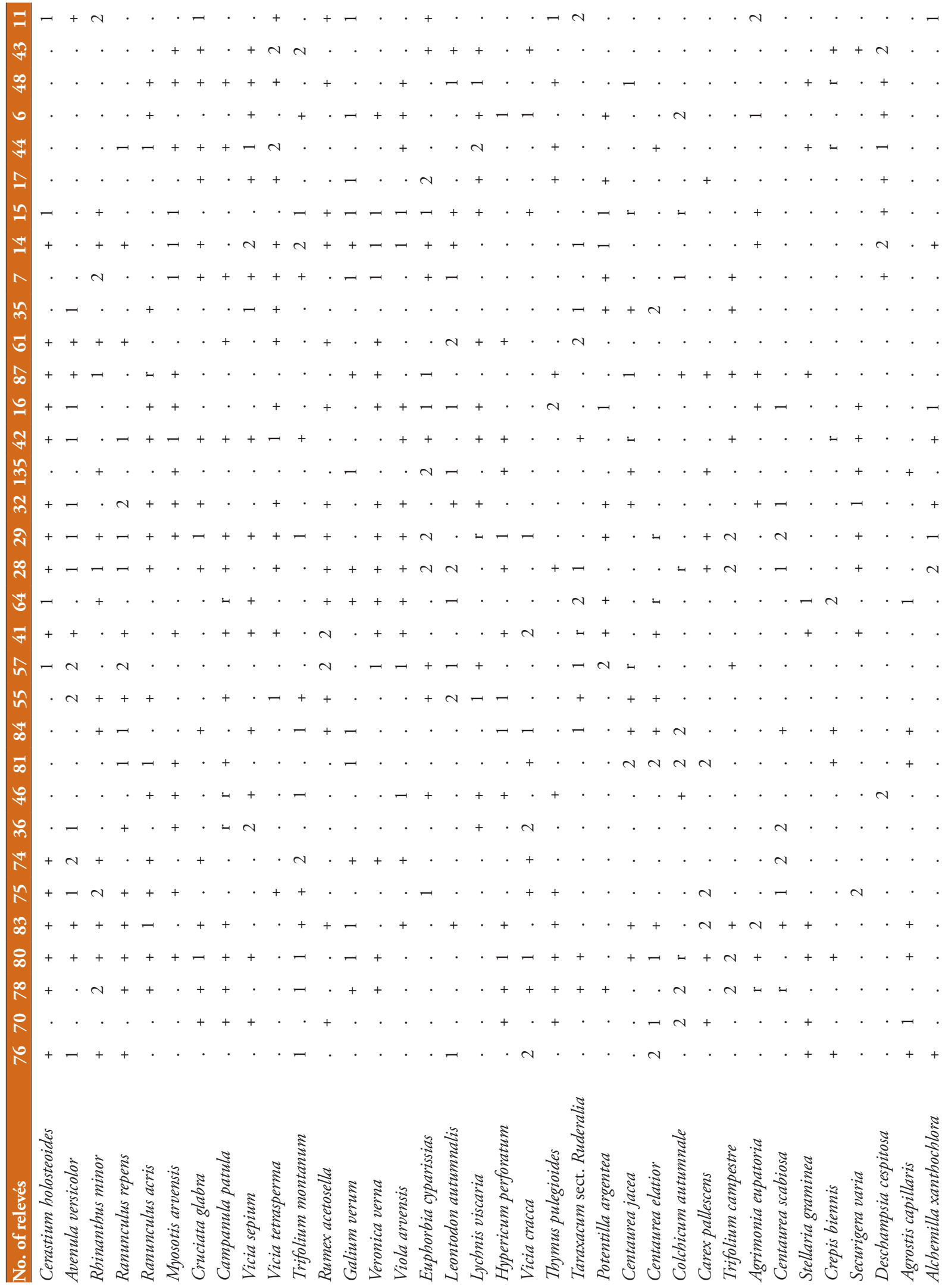




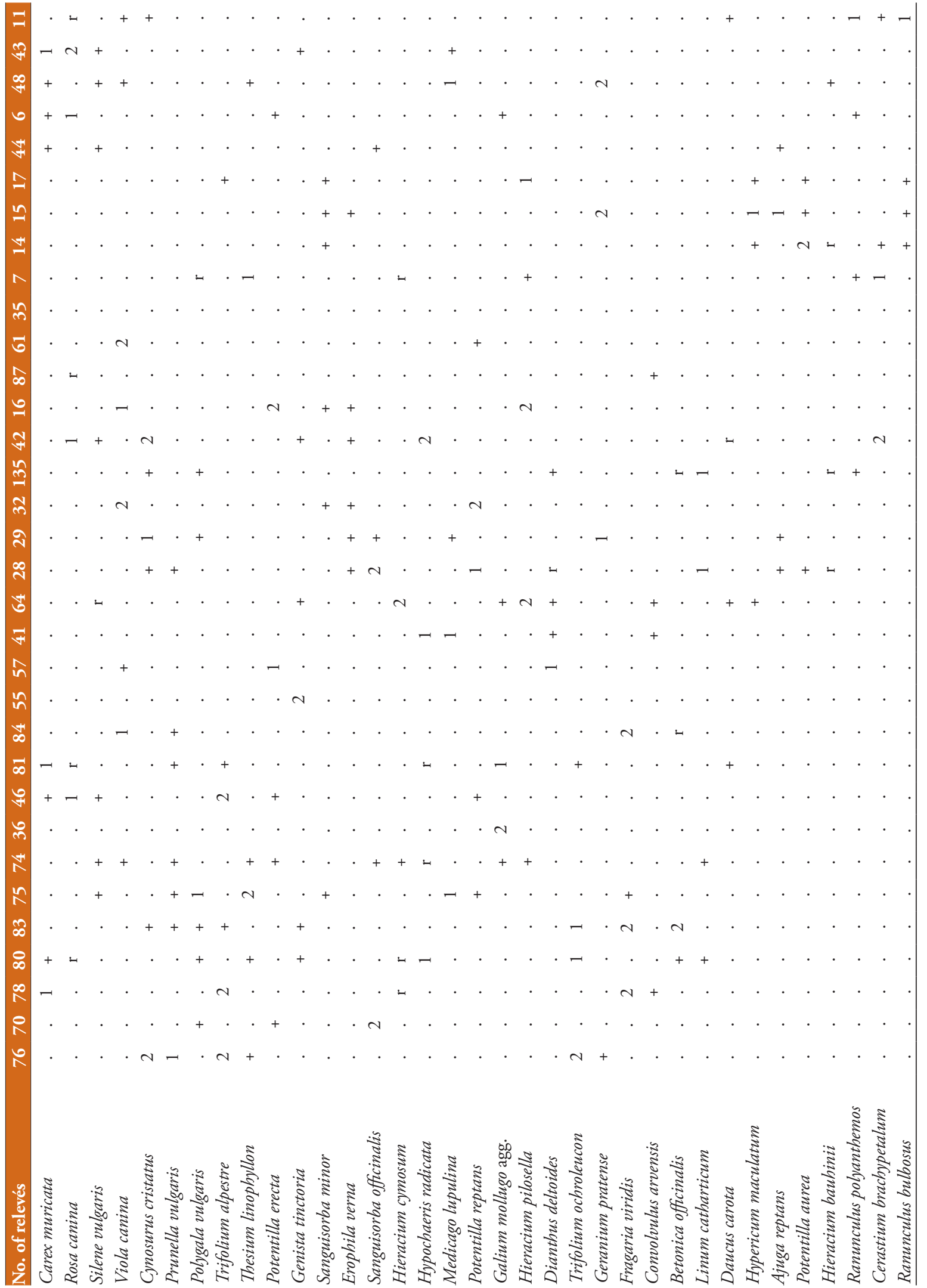




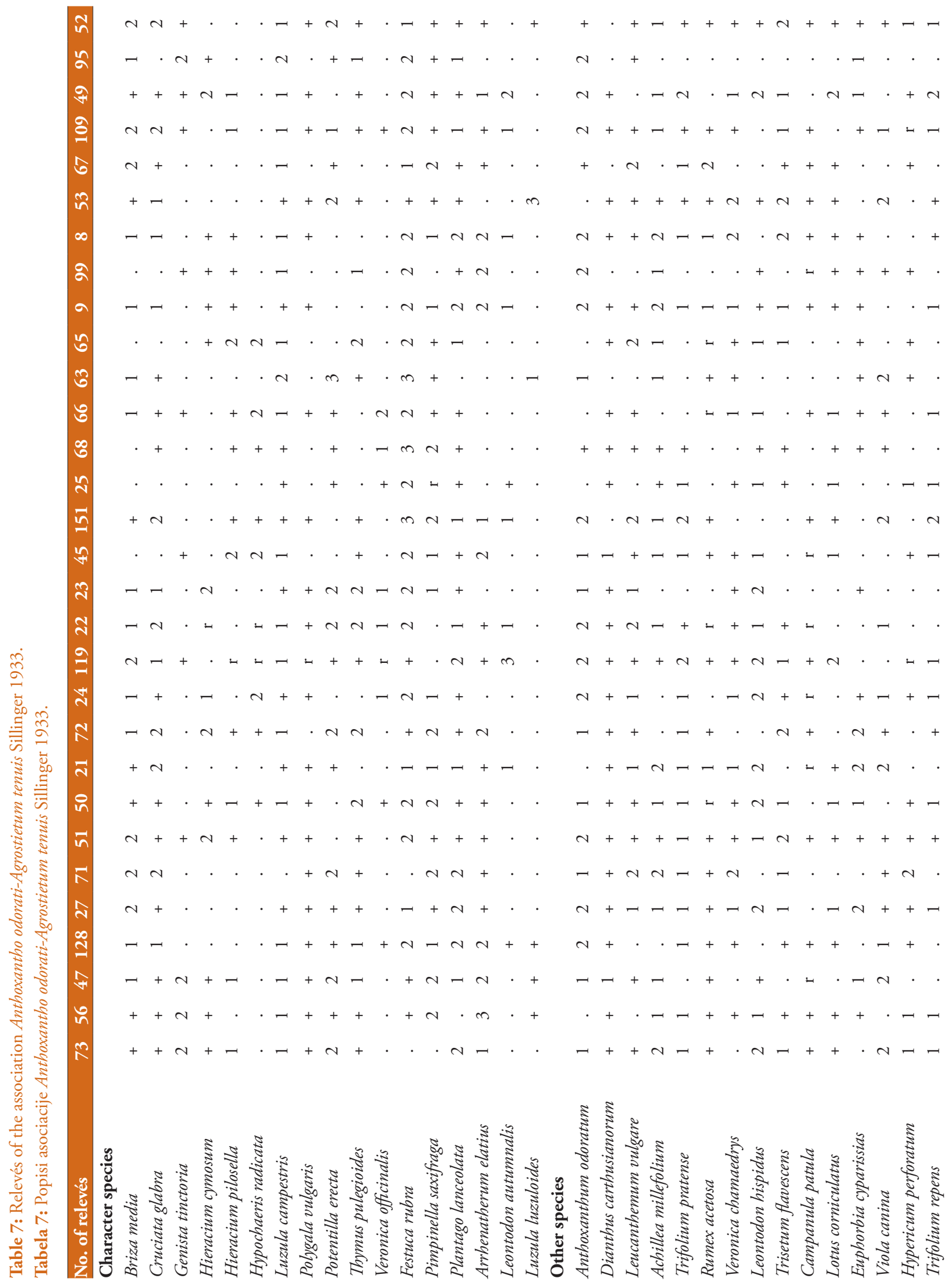




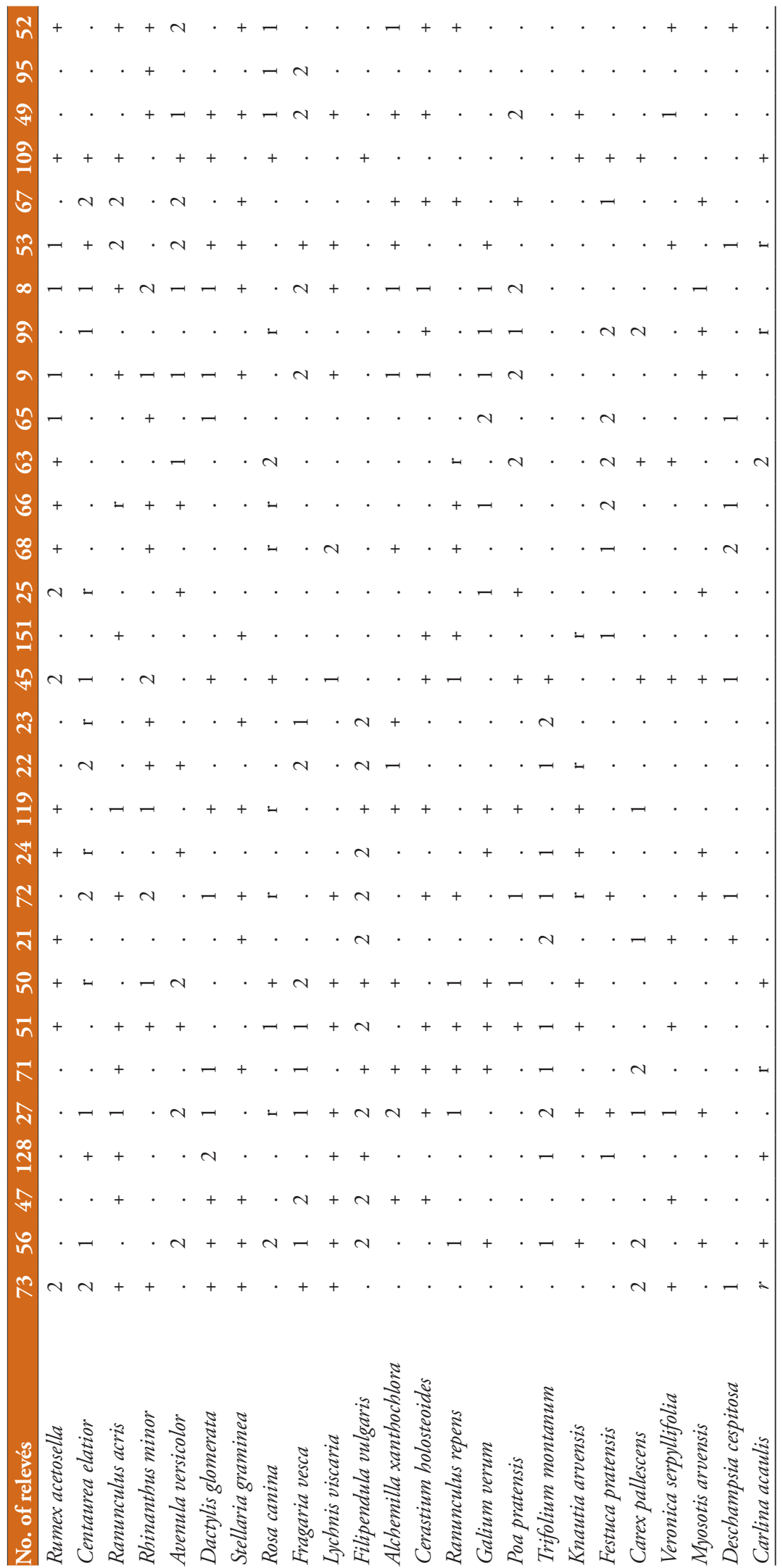


Table 8: Relevés of the alliance Bromion erecti Koch 1926.

Tabela 8: Popisi zveze Bromion erecti Koch 1926.

\begin{tabular}{|c|c|c|c|c|c|c|c|c|c|c|c|c|}
\hline No. of relevés & 143 & 149 & 125 & 147 & 144 & 127 & 88 & 145 & 90 & 89 & 94 & 146 \\
\hline \multicolumn{13}{|l|}{ Character species } \\
\hline Avenella flexuosa & . & . & . & + & 1 & + & . & 3 & . & . & . & 1 \\
\hline Avenula pubescens & + & 1 & 1 & + & 2 & 2 & 1 & . & 2 & 2 & 2 & 1 \\
\hline Brachypodium pinnatum & . & . & 4 & + & . & . & 2 & . & . & 2 & . & 2 \\
\hline Campanula persicifolia & + & . & $\mathrm{r}$ & . & 1 & $\mathrm{r}$ & . & . & . & . & . & + \\
\hline Geranium sanguineum & 2 & $\mathrm{r}$ & 2 & 1 & + & + & . & . & . & 2 & . & 2 \\
\hline Silene nutans s.lat. & + & . & $\mathrm{r}$ & + & + & . & . & . & . & . & . & + \\
\hline Trifolium alpestre & 1 & + & + & 1 & + & + & + & . & . & + & . & 1 \\
\hline Anthoxanthum odoratum & . & 2 & + & 2 & . & + & + & 1 & 2 & 1 & 2 & 1 \\
\hline Arrhenatherum elatius & 1 & 2 & + & 2 & 2 & + & . & 2 & 1 & 2 & 2 & 2 \\
\hline Festuca rubra & 2 & 3 & 2 & 2 & 2 & 2 & 1 & 2 & 2 & . & 1 & 1 \\
\hline Luzula campestris & + & . & + & + & + & + & + & 1 & 1 & 1 & + & . \\
\hline Pimpinella saxifraga & 1 & + & . & 1 & + & + & + & 1 & + & + & + & + \\
\hline Brachypodium pinnatum & . & . & 4 & + & . & . & 2 & . & . & 2 & . & 2 \\
\hline \multicolumn{13}{|l|}{ Other species } \\
\hline Dianthus carthusianorum & 1 & + & . & + & 1 & + & + & + & + & . & + & . \\
\hline Briza media & + & . & 1 & 1 & 2 & + & + & + & 1 & . & . & 1 \\
\hline Euphorbia cyparissias & + & . & + & + & + & . & + & 1 & 1 & . & + & 1 \\
\hline Lychnis viscaria & + & . & + & + & + & . & + & + & + & + & . & + \\
\hline Rumex acetosa & + & . & + & $\mathrm{r}$ & + & + & + & . & + & 1 & + & . \\
\hline Rosa canina s.lat. & $\mathrm{r}$ & . & $\mathrm{r}$ & $\mathrm{r}$ & + & $\mathrm{r}$ & $\mathrm{r}$ & + & $\mathrm{r}$ & . & 1 & . \\
\hline Plantago lanceolata & . & + & + & 1 & . & + & . & + & + & + & + & + \\
\hline Lotus corniculatus & . & + & + & + & + & + & + & + & . & + & . & + \\
\hline Achillea millefolium & . & . & + & + & . & + & + & + & 1 & 1 & 1 & + \\
\hline Hypericum perforatum & + & + & 1 & + & + & $\cdot$ & . & . & + & . & 1 & + \\
\hline Trisetum flavescens & + & + & 1 & + & . & + & . & 2 & 1 & . & . & 2 \\
\hline Stellaria graminea & + & . & + & + & + & + & . & + & . & + & . & + \\
\hline Thymus pulegioides & . & + & + & + & + & . & . & + & + & . & 1 & + \\
\hline Leontodon hispidus & . & . & 1 & 2 & 2 & + & 1 & $\cdot$ & 1 & 1 & . & 2 \\
\hline Trifolium montanum & . & . & + & 1 & + & + & 1 & . & 1 & 1 & . & 2 \\
\hline Veronica chamaedrys & . & . & + & . & + & 1 & + & + & . & + & + & 1 \\
\hline Rumex acetosella s.lat. & 2 & + & + & . & 2 & + & . & 1 & + & . & . & . \\
\hline Fragaria vesca & 2 & . & . & . & 1 & . & + & 1 & 2 & 2 & . & 1 \\
\hline Galium verum & 1 & 1 & . & . & 1 & . & + & . & + & + & + & . \\
\hline Agrostis capillaris & 1 & . & + & 2 & 1 & 1 & . & 1 & . & . & . & 1 \\
\hline Centaurea jacea & . & $\mathrm{r}$ & . & + & + & . & 1 & . & 1 & . & 1 & + \\
\hline Knautia arvensis & . & . & + & + & $\mathrm{r}$ & . & 1 & . & . & 1 & $\mathrm{r}$ & + \\
\hline Thesium linophyllon & 1 & . & + & + & 2 & + & . & . & . & $\cdot$ & . & 1 \\
\hline Hieracium pilosella & + & + & . & + & 1 & . & . & 1 & . & . & . & + \\
\hline Filipendula vulgaris & . & . & 2 & + & . & + & 1 & . & . & 1 & . & + \\
\hline Salvia pratensis & . & . & + & 1 & . & . & 2 & . & 1 & 1 & . & + \\
\hline Cruciata glabra & . & . & + & + & + & 1 & . & + & . & . & . & 1 \\
\hline Trifolium pratense & . & $\cdot$ & . & + & $\cdot$ & $\cdot$ & 1 & $\cdot$ & 1 & 1 & 1 & + \\
\hline Poa angustifolia & . & + & + & . & + & + & . & + & . & $\cdot$ & $\cdot$ & . \\
\hline Vicia sepium & . & + & . & . & . & $\cdot$ & + & . & 1 & + & + & . \\
\hline Viola canina & . & $\cdot$ & + & . & . & 2 & $\cdot$ & + & . & 1 & + & . \\
\hline Ranunculus bulbosus & . & . & + & $\cdot$ & . & + & . & . & 1 & 2 & + & . \\
\hline Leucanthemum vulgare & . & . & $\mathrm{r}$ & + & . & + & . & . & 1 & . & $\cdot$ & + \\
\hline Leontodon autumnalis & . & . & . & 1 & 1 & + & . & . & . & . & 1 & 1 \\
\hline Ranunculus repens & . & . & . & 1 & . & . & + & + & $\mathrm{r}$ & . & . & + \\
\hline Teucrium chamaedrys & 2 & . & . & + & . & . & $\cdot$ & + & $\cdot$ & . & 1 & . \\
\hline Potentilla argentea agg. & 1 & 1 & . & . & . & . & + & . & + & . & . & . \\
\hline
\end{tabular}




\begin{tabular}{|c|c|c|c|c|c|c|c|c|c|c|c|c|}
\hline No. of relevés & 143 & 149 & 125 & 147 & 144 & 127 & 88 & 145 & 90 & 89 & 94 & 146 \\
\hline Hieracium baubinii & 1 & . & $\cdot$ & + & $\cdot$ & $\cdot$ & $\cdot$ & $\cdot$ & $\mathrm{r}$ & . & $\cdot$ & + \\
\hline Carex caryophyllea & + & 1 & + & . & . & . & + & . & . & . & . & . \\
\hline Poa compressa & + & . & . & . & + & . & + & . & . & . & 1 & . \\
\hline Trifolium campestre & . & 1 & + & . & . & . & . & . & + & . & . & + \\
\hline Luzula multiflora s.lat. & . & 1 & . & . & . & + & . & + & . & . & . & + \\
\hline Sanguisorba minor & . & + & 1 & + & . & . & . & . & 1 & . & . & . \\
\hline Cerastium holosteoides & . & + & + & . & . & . & . & + & . & . & . & + \\
\hline Veronica officinalis & . & + & $\mathrm{r}$ & . & . & . & . & + & . & . & . & + \\
\hline Centaurea phrygia & . & $\mathrm{r}$ & . & . & 1 & . & . & + & . & . & . & + \\
\hline Alchemilla xanthochlora & . & . & 1 & 1 & . & + & . & . & . & . & . & 1 \\
\hline Dactylis glomerata & . & . & . & 1 & . & + & + & . & . & . & . & + \\
\hline Hypochaeris maculata & . & . & . & + & 2 & $\mathrm{r}$ & . & . & . & . & . & + \\
\hline Carlina acaulis & . & . & . & + & 1 & $\mathrm{r}$ & . & . & . & . & . & + \\
\hline Tragopogon orientalis & . & . & . & + & + & . & . & . & . & . & 1 & + \\
\hline Phleum pratense & 1 & . & + & . & + & . & . & . & . & . & . & . \\
\hline Primula elatior & . & . & 1 & + & . & 1 & . & . & . & . & . & . \\
\hline Anthyllis vulneraria & . & . & + & 2 & . & + & . & . & . & . & . & . \\
\hline Potentilla erecta & . & . & + & . & . & 1 & . & . & . & . & . & + \\
\hline Trifolium repens & . & . & . & + & + & + & . & . & . & . & . & . \\
\hline Nardus stricta & . & . & . & + & . & 1 & . & 2 & . & $\cdot$ & . & $\cdot$ \\
\hline Polygala vulgaris & . & . & . & + & . & + & . & . & . & . & . & + \\
\hline Bromus erectus & . & . & . & + & . & . & 2 & . & . & 2 & . & . \\
\hline Trifolium ochroleucon & . & . & . & + & . & . & + & . & . & . & . & + \\
\hline Alopecurus pratensis & . & . & . & . & . & + & + & . & 1 & . & . & . \\
\hline Poa pratensis & . & . & . & . & . & $\cdot$ & 1 & . & 2 & 1 & . & . \\
\hline Vicia tetrasperma & . & . & . & . & . & . & + & . & + & . & + & . \\
\hline Orchis morio & . & . & . & . & . & . & 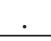 & . & 1 & + & . & $\mathrm{r}$ \\
\hline
\end{tabular}

Table 9: Relevés of the association Onobrychido viciifoliae-Brometum erecti T.Müller 1966.

Tabela 9: Popisi asociacije Onobrychido viciifoliae-Brometum erecti T.Müller 1966.

No. of relevés $107 \quad 124 \quad 105 \quad 126 \quad 106$

Character species

Bromus erectus

Avenula pubescens

Campanula rapunculoides

Linum catharticum

Medicago falcata

Medicago lupulina

Primula elatior

Ranunculus bulbosus

Sanguisorba minor

Securigera varia

Dactylis glomerata

Dianthus carthusianorum

Festuca rubra

Plantago lanceolata

Salvia pratensis

Geranium sanguineum

Other species

Poa angustifolia

Leontodon autumnalis

Carex caryophyllea

\section{No. of relevés}

$\begin{array}{lllll}107 \quad 124 & 105 \quad 126 \quad 106\end{array}$

Rosa canina s.lat

Pimpinella saxifraga s.str.

Tragopogon orientalis

Knautia arvensis

Centaurea scabiosa

Cerastium holosteoides

Lotus corniculatus

Trisetum flavescens

Vicia cracca

Arrhenatherum elatius

Prunus domestica

Polygala vulgaris

Euphorbia cyparissias

Trifolium montanum

Anthyllis vulneraria

Leontodon hispidus

Trifolium repens

Trifolium pratense

Leucanthemum vulgare

Veronica chamaedrys 


\section{Appendix}

Table 1: Original relevé number, coordinates, altitude $/ \mathrm{m} /$, aspect, slope, heath-index, cover of herb layer $/ \% /$, number of species:

Association Holcetum lanati (Group No. 1). Sites: 1. N48 $27^{\prime} 55^{\prime \prime}$

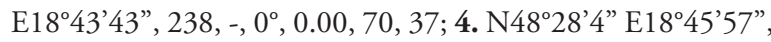
251, NE, $10^{\circ}, 0.59$, 80, 38; 20. N48 $27^{\prime} 16^{\prime \prime} \mathrm{E} 18^{\circ} 49^{\prime} 16^{\prime \prime}, 500$, E, $10^{\circ}, 0.59,70,33 ; 6$ 6. N48 $29^{\prime} 43^{\prime \prime}$ E $18^{\circ} 47^{\prime} 31^{\prime \prime}, 777,-, 0^{\circ}$, $0.00,100,31$; 91. N4822'21" E18 $38^{\prime} 37^{\prime \prime}, 387,-, 0^{\circ}, 0.00$,

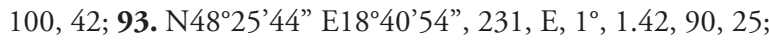
103. N4830'30" E18 $46^{\circ} 37^{\prime \prime}, 261,-, 0^{\circ}, 0.00,80,38 ; 104$.

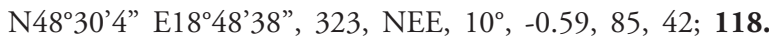
N48 $30^{\prime} 4^{\prime \prime}$ E1 $8^{\circ} 50^{\prime} 22^{\prime \prime}, 369$, E, 5, $-3.09,100,33$;

Association Pastinaco sativae-Arrhenatheretum elatioris - intensified meadows (Group No. 2). Sites: 2. N48 27'44" E18 $43^{\circ} 46^{\prime \prime}$, 233, -, $0^{\circ}, 0.00,95,34 ; 3 . \mathrm{N}^{\circ} 8^{\circ} 27^{\prime} 41^{\prime \prime} \mathrm{E} 18^{\circ} 43^{\prime} 43^{\prime \prime}, 235,-, 0^{\circ}$, $0.00,100,35 ;$; $98 . \mathrm{N}^{\circ} 23^{\circ} 22^{\prime \prime} \mathrm{E} 18^{\circ} 38^{\prime} 50^{\prime \prime}, 278,-, 0^{\circ}, 0.00$, 85, 28; 101. N48 $23^{\prime} 2^{\prime \prime} \mathrm{E} 18^{\circ} 38^{\prime} 11^{\prime \prime}, 277,-, 0^{\circ}, 0.00,80,37$; 102. N4823’31' E $18^{\circ} 38^{\prime} 29^{\prime \prime}, 369,-, 0^{\circ}, 0.00,85,26$;

Association Pastinaco sativae-Arrhenatheretum elatioris (Group No. 3) Sites: 5. N48 $28^{\prime} 7^{\prime \prime}$ E1 $18^{\circ} 45^{\prime} 55^{\prime \prime}, 459$, W, $15^{\circ}, 0.75$, 95, 48; 10. N48 $28^{\prime} 10^{\prime \prime} \mathrm{E} 18^{\circ} 45^{\prime} 40^{\prime \prime}, 489$, W, $10^{\circ},-0.57$, 100,$31 ; 12.8^{\circ} 28^{\prime} 14^{\prime \prime} \mathrm{E} 18^{\circ} 45^{\prime} 28^{\prime \prime}, 462, \mathrm{SE}, 5^{\circ},-2.80$, 95, 37; 13. N48 $28^{\prime} 15^{\prime \prime} \mathrm{E} 18^{\circ} 45^{\prime} 21^{\prime \prime}, 438,-, 0^{\circ}, 0.00,85$, 27; 19. N48 $27^{\prime} 16^{\prime \prime} \mathrm{E} 18^{\circ} 49^{\prime} 10^{\prime \prime}, 476, \mathrm{E}, 5^{\circ},-3.09,80$, 30; 30. N48 $26^{\prime} 26^{\prime \prime} \mathrm{E} 18^{\circ} 47^{\prime} 30^{\prime \prime}, 608$, NE, $10^{\circ}, 0.59,95$, 56; 31. N4826'22" E18 $47^{\prime} 30^{\prime \prime}, 610, \mathrm{E}, 15^{\circ},-0.78,75$, 42; 34. N4826'14" E1847'45”, 619, -, $0^{\circ}, 0.00,100,31$; 38. N48 $26^{\prime} 10^{\prime \prime}$ E18 $48^{\prime} 16^{\prime \prime}, 712, \mathrm{NW}, 12^{\circ}, 0.03,95,41$; 39. N48 $26^{\prime} 19^{\prime \prime} \mathrm{E} 18^{\circ} 48^{\prime} 17^{\prime \prime}, 623, \mathrm{~S}, 10^{\circ},-0.03,100,32$; 40. N4826 $39^{\prime \prime}$ E $18^{\circ} 48^{\prime} 2^{\prime \prime}, 596, \mathrm{~S}, 10^{\circ},-0.03,95,50 ; 54$.

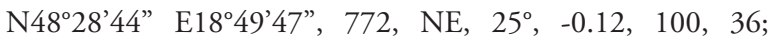
59. N48 $26^{\prime} 9^{\prime \prime} \mathrm{E} 18^{\circ} 47^{\prime} 46^{\prime \prime}, 609, \mathrm{~W}, 5^{\circ}, 2.95,100,44 ; 60$.

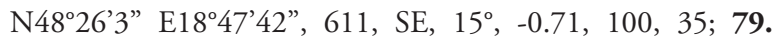
N48 30'53" E1847'30", 391, SW, 5', 2.95, 95, 54; 85. N48 $20^{\prime} 1^{\prime \prime}$ E $18^{\circ} 40^{\prime} 31^{\prime \prime}, 489,-, 0^{\circ}, 0.00,90,34 ; 96 . N^{\circ} 48^{\circ} 25^{\prime} 41^{\prime \prime}$ E18 $41^{\prime} 24^{\prime \prime}, 249, \mathrm{E}, 1^{\circ}, 1.42,85,36 ; 97 . \mathrm{N} 48^{\circ} 25^{\prime} 54^{\prime \prime}$ E18 $41^{\prime} 28^{\prime \prime}, 232, \mathrm{E}, 1^{\circ}, 1.42,80,35 ; 100 . \mathrm{N} 48^{\circ} 23^{\prime} 23^{\prime \prime}$ E18 $38^{\prime} 21^{\prime \prime}, 279,-, 0^{\circ}, 0.00,85,33 ; 110 . N 48^{\circ} 32^{\prime} 2^{\prime \prime} \mathrm{E} 18^{\circ} 56^{\prime} 39^{\prime \prime}$, $690,-, 0^{\circ}, 0.00,85,40 ; 112 . \mathrm{N}^{\circ} 32^{\prime} 29^{\prime \prime} \mathrm{E} 18^{\circ} 55^{\prime} 60^{\prime \prime}, 617$, NW, $1^{\circ},-0.07,90,38 ; 113 . \mathrm{N}^{\circ} 32^{\prime} 12^{\prime \prime} \mathrm{E} 18^{\circ} 56^{\prime} 20^{\prime \prime}, 690$, NEE, $3^{\circ}, 0.13,95,37 ; 114.4^{\circ} 32^{\prime} 59^{\prime \prime}$ E18 $8^{\circ} 57^{\prime} 17^{\prime \prime}, 653$, SE, $3^{\circ},-0.12,95,43 ; 115.8^{\circ} 32^{\prime} 52^{\prime \prime}$ E $18^{\circ} 57^{\prime} 23^{\prime \prime}, 643$, E, $5^{\circ},-3.09,90,46 ; 116 . \mathrm{N}^{\circ} 33^{\prime} 23^{\prime \prime} \mathrm{E} 18^{\circ} 56^{\prime} 28^{\prime \prime}, 658$, SSW, $3^{\circ},-0.01,95,44 ; 120 . \mathrm{N} 48^{\circ} 31^{\prime} 5^{\prime \prime} \mathrm{E} 18^{\circ} 50^{\prime} 41^{\prime \prime}, 488, \mathrm{NE}, 3^{\circ}$, $-0.13,100,45 ; 123 . \mathrm{N}^{\circ} 29^{\prime} 41^{\prime \prime} \mathrm{E} 18^{\circ} 51^{\prime} 51^{\prime \prime}, 735, \mathrm{~N}, 1^{\circ}, 1.29$, 100, 36; 136. N48 $26^{\prime} 47^{\prime \prime}$ E1 $18^{\circ} 51^{\prime} 50^{\prime \prime}, 312$, NEE, $7^{\circ},-0.79$, 90, 22; 138. N4826'14” E1 $18^{\circ} 50^{\prime} 42^{\prime \prime}, 472$, SW, $1^{\circ},-1.36,85$,

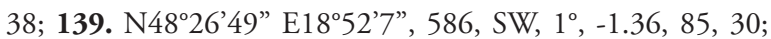

140. N4828'43” E18 $52^{\prime} 16^{\prime \prime}, 583, \mathrm{~S}, 3^{\circ}, 0.01,90,41 ; 152$.

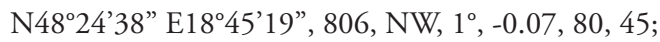

Association Alchemillo - Arrhenatheretumelatioris (Group No. 4) Sites: 18. N48 $27^{\prime} 19^{\prime \prime}$ E $18^{\circ} 49^{\prime} 5^{\prime \prime}, 458,-, 0^{\circ}, 0.00,80,28 ; 26$. N48 $26^{\prime} 28^{\prime \prime}$ E1 $18^{\circ} 47^{\prime} 4^{\prime \prime}, 602,-, 0^{\circ}, 0.00,95,53 ; 33 . N 48^{\circ} 26^{\prime} 12^{\prime \prime}$ E18 $47^{\prime} 41^{\prime \prime}, 619,-, 0^{\circ}, 0.00,80,51 ; 37 . N 48^{\circ} 25^{\prime} 59^{\prime \prime} \mathrm{E} 18^{\circ} 48^{\prime} 19^{\prime \prime}$,

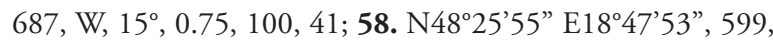

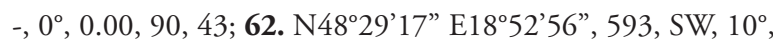
$-0.57,85,48 ; 77$. N48 $30^{\circ} 45^{\prime \prime}$ E $18^{\circ} 47^{\prime} 56^{\prime \prime}, 370$, SW, 5, 2.95, 95, 39; 82. N48 $23^{\prime} 40^{\prime \prime} \mathrm{E} 18^{\circ} 45^{\prime} 5^{\prime \prime}, 369,-, 0^{\circ}, 0.00,95,42 ; 86$. N48 $20^{\prime} 1^{\prime \prime}$ E $18^{\circ} 41^{\prime} 43^{\prime \prime}, 349,-, 0^{\circ}, 0.00,90,42 ; 92 . N 48^{\circ} 25^{\prime} 39^{\prime \prime}$ $\mathrm{E} 18^{\circ} 40^{\prime} 52^{\prime \prime}, 246,-, 0^{\circ}, 0.00,90,38 ; 108 . \mathrm{N} 48^{\circ} 30^{\prime} 2^{\prime \prime}$ $\mathrm{E} 18^{\circ} 50^{\prime} 11^{\prime \prime}, 623, \mathrm{~S}, 5^{\circ}, 0.15,95,51 ; 111 . \mathrm{N} 48^{\circ} 32^{\prime} 16^{\prime \prime}$ E18 $56^{\prime} 53^{\prime \prime}, 580, \mathrm{NNW}, 7^{\circ}, 0.03,80,49 ; 117 . \mathrm{N}^{\circ} 38^{\circ} 33^{\prime} 40^{\prime \prime} \mathrm{E}$ $19^{\circ} 0^{\prime} 8^{\prime \prime}, 471, \mathrm{~S}, 7^{\circ},-0.04,85,44 ; 121 . \mathrm{N} 48^{\circ} 31^{\prime} 5^{\prime \prime} \mathrm{E} 18^{\circ} 50^{\prime} 45^{\prime \prime}$, 512, S, 7, $-0.04,90,43$; 122. N48 $29^{\prime} 52^{\prime \prime}$ E $18^{\circ} 51^{\prime} 56^{\prime \prime}, 527$, NE, $1^{\circ}, 1.42,90,54 ; 129$. N48 $34^{\prime} 25^{\prime \prime}$ E $18^{\circ} 54^{\prime} 17^{\prime \prime}, 223$, SW, $7^{\circ},-0.76,100,35 ; 130.8^{\circ} 31^{\prime} 9^{\prime \prime}$ E $18^{\circ} 51^{\prime} 1$ '”, 250, SW, $1^{\circ}$, -1.36, 100, 34; 131. N48 $31^{\prime} 15^{\prime \prime}$ E1 $18^{\circ} 51^{\prime} 9^{\prime \prime}, 582,-, 0^{\circ}, 0.00$, 90, 44; 132. N4829'58” E1 $18^{\circ} 55^{\prime} 51^{\prime \prime}, 595$, NW, $1^{\circ},-0.07,100$, 37; 133. N4831'53" E185 ' '50", 648, NWW, $1^{\circ}, 1.35,75$, 43; 134. N4831'39”' E18 $52^{\circ} 51^{\prime \prime}, 679$, SW, $1^{\circ},-1.36,80,54$; 137. N4826 $31^{\prime \prime}$ E1 $18^{\circ} 51^{\prime} 7^{\prime \prime}, 469, \mathrm{~N}, 5^{\circ},-2.80,80,53 ; 141$. N48 $28^{\prime} 60^{\prime \prime}$ E $18^{\circ} 45^{\prime} 8^{\prime \prime}, 356$, SSW, 30 $30^{\circ},-0.34,75,16 ; 142$. N48 $28^{\prime} 42^{\prime \prime}$ E18 $45^{\prime} 6^{\prime \prime}, 418$, SWW, 20', 1.96, 90, 46; 148. N48 $27^{\prime} 41^{\prime \prime}$ E1 $18^{\circ} 52^{\prime} 51^{\prime \prime}, 734, \mathrm{NNE}, 3^{\circ}, 0.12,80,38 ; 150$.

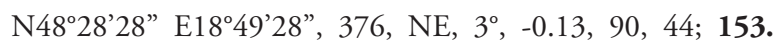

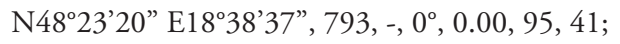

Alliance Arrhenatherion elatioris- succesion stages (Group No. 5) Sites: 6. N4828'14" E18 $46^{\circ} 2^{\prime \prime}, 475$, W, $15^{\circ}, 0.75$, 100, 43; 7. N48 $28^{\prime} 20^{\prime \prime} \mathrm{E} 18^{\circ} 46^{\prime} 9^{\prime \prime}, 497, \mathrm{NW}, 10^{\circ},-0.03$,

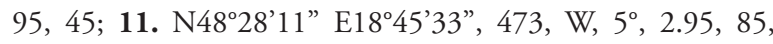

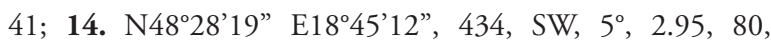
45; 15. N48 $27^{\prime} 23^{\prime \prime}$ E18 $8^{\circ} 47^{\prime} 26^{\prime \prime}, 417, S, 5^{\circ}, 0.15,90,49$; 16. N48 $27^{\prime} 24^{\prime \prime} \mathrm{E} 18^{\circ} 48^{\prime} 22^{\prime \prime}, 461, \mathrm{E}, 20^{\circ}, 2.04,75,50$; 17. N48 $27^{\prime} 15^{\prime \prime}$ E18 $49^{\prime} 1$ ', 433, W, 15, 0.75, 95, 31; 28.

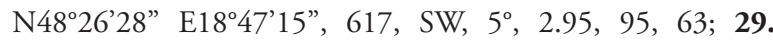

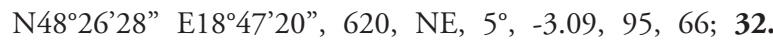
N48 $26^{\prime} 22^{\prime \prime} \mathrm{E} 18^{\circ} 47^{\prime} 33^{\prime \prime}, 604,-, 0^{\circ}, 0.00,75,51 ; 35 . \mathrm{N}^{\circ} 28^{\circ}{ }^{\prime} 54^{\prime \prime}$ E1 $8^{\circ} 48^{\prime} 0^{\prime \prime}, 620, \mathrm{NE}, 10^{\circ}, 0.59,100,31 ; 36 . \mathrm{N} 48^{\circ} 26^{\prime} 2^{\prime \prime}$ E18 48'30", 623, SW, $10^{\circ},-0.57,95,24 ;$ 41. N48 $26^{\circ} 32^{\prime \prime}$ E18 $48^{\prime} 9^{\prime \prime}, 563,-, 0^{\circ}, 0.00,80,43 ; 42 . N^{\circ} 8^{\circ} 27^{\prime} 32^{\prime \prime}$ E $18^{\circ} 46^{\prime} 12^{\prime \prime}$,

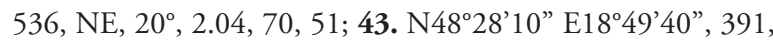
NW, 20 $,-0.10,100,30 ; 44$. N48 $^{\circ} 28^{\prime} 10^{\prime \prime}$ E $18^{\circ} 49^{\prime} 30^{\prime \prime}, 606$, NW, $20^{\circ},-0.10,95,48 ; 46 . \mathrm{N} 48^{\circ} 28^{\prime} 7^{\prime \prime} \mathrm{E} 18^{\circ} 49^{\prime} 10^{\prime \prime}, 594$, SE, $10^{\circ}, 0.54,80,42$; 48. N48 $28^{\prime} 51^{\prime \prime}$ E1 $18^{\circ} 49^{\prime} 34^{\prime \prime}, 506$, SW, $25^{\circ}, 0.12,100,49 ; 55 . \mathrm{N}^{\circ} 25^{\circ} 48^{\prime \prime} \mathrm{E} 18^{\circ} 47^{\prime} 49^{\prime \prime}, 738,-, 0^{\circ}$, $0.00,95,35$; 57. N48 $25^{\prime} 51^{\prime \prime} \mathrm{E} 18^{\circ} 47^{\prime} 52^{\prime \prime}, 604,-, 0^{\circ}, 0.00$, 85, 35; 61. N48 $28^{\prime} 47^{\prime \prime} \mathrm{E} 18^{\circ} 52^{\prime} 56^{\prime \prime}, 617, \mathrm{SW}, 10^{\circ},-0.57$, 95, 39; 64. N4828’41" E1 $8^{\circ} 52^{\prime} 54^{\prime \prime}, 816,-, 0^{\circ}, 0.00,80,48$;

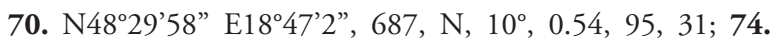
N48 $29^{\prime} 57^{\prime \prime} \mathrm{E} 18^{\circ} 48^{\prime} 2^{\prime \prime}, 402,-, 0^{\circ}, 0.00,80,47 ; 75 . \mathrm{N} 48^{\circ} 30^{\prime} 42^{\prime \prime}$ 
E184' 39", 411, -, $0^{\circ}, 0.00,85,42 ; 76 . \quad N 48^{\circ} 30^{\prime} 34^{\prime \prime}$ E18 $47^{\prime} 54^{\prime \prime}, 437, \mathrm{~N}, 5^{\circ},-2.80,95,41 ; 78 . \mathrm{N} 48^{\circ} 30^{\prime} 58^{\prime \prime}$

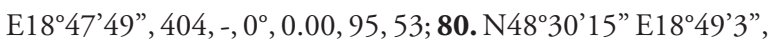
362, -, $0^{\circ}, 0.00,80,62 ; 81 . \mathrm{N} 48^{\circ} 30^{\prime} 11^{\prime \prime} \mathrm{E} 18^{\circ} 49^{\prime} 23^{\prime \prime}, 334, \mathrm{~S}$, $5^{\circ}, 0.15,100,42 ; 83 . \mathrm{N}^{\circ} 23^{\prime} 54^{\prime \prime} \mathrm{E} 18^{\circ} 45^{\prime} 8^{\prime \prime}, 485,-, 0^{\circ}, 0.00$, 95, 60; 84. N48 24'7” E18 45'22”, 511, 0, $0^{\circ}, 0.00,100,43$; 87. N4819'54” E1841'39", 322, SW, 5, 2.95, 90, 47; 135. N4826'51" E18 51'52”, 307, NW, 3, 0.01, 80, 45;

Association Anthoxantho odorati - Agrostietum tenuis (Group

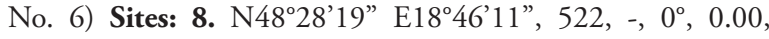
100, 53; 9. N4828'8" E18 45'45”, 512, -, $0^{\circ}, 0.00,100$, 54; 21. N4827’19” E1849'22”, 518, -, 0, 0.00, 75, 38; 22. N4827'18” E18 49'21", 548, SW, 10, -0.57, 95, 44; 23. N4827'12” E1849'33”, 544, SW, 10, -0.57, 95, 42; 24.

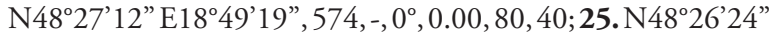

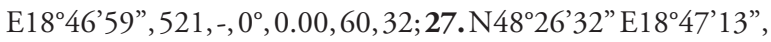
612, NE, $15^{\circ},-0.78,85,60$; 45. N48 28'10" E18 49'16”, $603,-, 0^{\circ}, 0.00,70,44 ; 47 . \mathrm{N} 48^{\circ} 28^{\prime} 47^{\prime \prime}$ E18 49'37”, 536, -, $0^{\circ}, 0.00,80,45 ; 49 . \mathrm{N} 48^{\circ} 28^{\prime} 41^{\prime \prime} \mathrm{E} 18^{\circ} 49^{\prime} 14 ”, 737, \mathrm{~W}$, 15 $, 0.75,95,51 ; 50 . \mathrm{N} 48^{\circ} 28^{\prime} 37^{\prime \prime} \mathrm{E} 18^{\circ} 48^{\prime} 48^{\prime \prime}, 766$, W, $5^{\circ}, 2.95,85,54 ; 51 . \mathrm{N} 48^{\circ} 28^{\prime} 42^{\prime \prime} \mathrm{E} 18^{\circ} 50^{\prime} 4 ”, 729, \mathrm{~W}, 10^{\circ}$, $-0.57,95,55 ;$ 52. N48 28'39" E18 $50^{\prime} 17^{\prime \prime}, 696, \mathrm{NE}, 15^{\circ}$, $-0.78,95,41 ; 53 . \mathrm{N}^{\circ} 28^{\prime} 49^{\prime \prime} \mathrm{E} 18^{\circ} 49^{\prime} 57^{\prime}$, 756, NE, 20', 2.04, 100, 44; 56. N48 25'46” E18 47'45”, 683, SW, $15^{\circ}$, $0.75,100,55$; 63. N48 28'52" E18 $53^{\prime} 10^{\prime}$, 761, NE, 5, -3.09, 80, 28; 65. N48 28'37" E18 $52^{\prime} 44^{\prime \prime}, 773, \mathrm{~S}, 10^{\circ}$, $-0.03,75,28 ; 66 . \mathrm{N}^{\circ} 28^{\circ} 35^{\prime \prime} \mathrm{E} 18^{\circ} 52^{\prime} 45^{\prime \prime}, 782,-, 0^{\circ}, 0.00$,

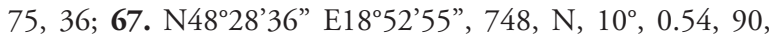

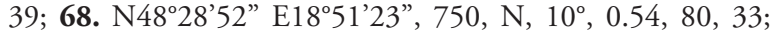
71. N48 29'35" E18 46'52", 414, NE, 5०, -3.09, 80, 46; 72. N48 30'2" E18 $47^{\prime} 17^{\prime \prime}, 350, \mathrm{NW}, 10^{\circ},-0.03,75,50$; 73. N48 29'54" E18 48'10", 413, -, 0०, 0.00, 95, 43; 95. N4825'18" E1841'28”, 323, SSW, 3, -0.01, 90, 27; 99. N4823'33" E18³8'50", 360, S, 1', -0.07, 95, 36; 109. N4830'44” E1855'19”, 626, -, 0, 0.00, 95, 54; m119. N4830'55" E18 51'10", 620, -, 0 , 0.00, 85, 55; 128. N48 18'17" E18³5'40”, 686, NNW, 5, -0.12, 80, 48; 151. N48²7'47” E1843'39”, 266, NE, 5, -3.09, 95, 33;

Alliance Bromion erecti (Group No. 7) Sites: 88. N48 $20^{\prime} 49^{\prime \prime}$ E18 42'5”, 476, -, 0 , 0.00, 100,39; 89. N48²0'49” E1841'55”, 452, -, $0^{\circ}, 0.00,95,36$; 90. N4821'12” E1842'44”, 452, -, $0^{\circ}, 0.00,90,43$; 94. N48 25'12" E18 41'32”, 294, SW, 5, 2.95, 90, 30; 125. N48 29'42" E18 $511^{\prime} 50^{\prime \prime}, 680$, SW, 25, 0.12 , 90, 57; 127. N48 28'54" E18 51'46”, 743, SE, 3, -0.12, 90, 52; 143. N4829'41" E18 44'18”, 872, NWW, 3ㅇ, -0.12, 70, 34; 144. N48 25'40” E1841'52”, 859, SW, 3º 0.12, 75, 44; 145. N48 17'51" E18³8'26”, 837, W, 10, -0.57, 85, 33; 146. N48 29'59" E18 55'32", 795, SWW, $1^{\circ}, 1.37,80,56$; 147. N48 27'59” E18 52'58”, 784, NW, 5º 0.15, 85, 59; 149. N4830'13” E1848'22”, 373, SWW, 3, -0.13, 80, 33;

Association Onobrychido viciifoliae-Brometum erecti (Group No. 8) Sites: 105. N48 30'7” E18 48'40”, 403, SW, 3, 0.12, 100, 60; 106. N48³0'0" E18 49'9”, 427, SE, 5, -2.80, 95,

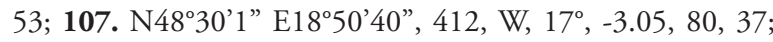
124. N4829'30” E $18^{\circ} 51^{\prime} 51^{\prime}, 750, \mathrm{~N}, 25^{\circ},-0.11,75,47 ; 126$.

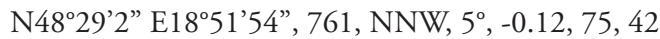

